\title{
On inclusion of water resource management in Earth system models - Part 2: Representation of water supply and allocation and opportunities for improved modeling
}

\author{
A. Nazemi and H. S. Wheater \\ Global Institute for Water Security, University of Saskatchewan, 11 Innovation Boulevard, Saskatoon, SK S7N 3H5, Canada \\ Correspondence to: A. Nazemi (ali.nazemi@usask.ca)
}

Received: 12 June 2014 - Published in Hydrol. Earth Syst. Sci. Discuss.: 21 July 2014

Revised: 11 November 2014 - Accepted: 25 November 2014 - Published: 7 January 2015

\begin{abstract}
Human water use has significantly increased during the recent past. Water withdrawals from surface and groundwater sources have altered terrestrial discharge and storage, with large variability in time and space. These withdrawals are driven by sectoral demands for water, but are commonly subject to supply constraints, which determine water allocation. Water supply and allocation, therefore, should be considered together with water demand and appropriately included in Earth system models to address various large-scale effects with or without considering possible climate interactions. In a companion paper, we review the modeling of demand in large-scale models. Here, we review the algorithms developed to represent the elements of water supply and allocation in land surface and global hydrologic models. We note that some potentially important online implications, such as the effects of large reservoirs on land-atmospheric feedbacks, have not yet been fully investigated. Regarding offline implications, we find that there are important elements, such as groundwater availability and withdrawals, and the representation of large reservoirs, which should be improved. We identify major sources of uncertainty in current simulations due to limitations in data support, water allocation algorithms, host large-scale models as well as propagation of various biases across the integrated modeling system. Considering these findings with those highlighted in our companion paper, we note that advancements in computation and coupling techniques as well as improvements in natural and anthropogenic process representation and parameterization in host large-scale models, in conjunction with remote sensing and data assimilation can facilitate inclusion of water resource management at larger scales. Nonetheless, various modeling options should
\end{abstract}

be carefully considered, diagnosed and intercompared. We propose a modular framework to develop integrated models based on multiple hypotheses for data support, water resource management algorithms and host models in a unified uncertainty assessment framework. A key to this development is the availability of regional-scale data for model development, diagnosis and validation. We argue that the time is right for a global initiative, based on regional case studies, to move this agenda forward.

\section{Introduction}

The water cycle is fundamental to the functioning of the Earth system and underpins the most basic needs of human society. However, as noted in our companion paper (hereafter referred to as Nazemi and Wheater, 2015), the current scale of human activities significantly perturbs the terrestrial water cycle, with local, regional and global implications. Such disturbances affect both hydrological functioning and land-atmospheric interactions, and therefore should be explicitly represented in large-scale models. We consider both land surface models (LSMs) and global hydrologic models (GHMs). LSMs generally represent water, energy and carbon cycles, and can be coupled with climate models (i.e., online simulations) for integrated Earth system modeling, or uncoupled from climate models (i.e., offline simulations) for large-scale impact assessment. GHMs are also run in uncoupled mode for impact assessment; however, they focus exclusively on the water cycle. In this survey, we consider the representation of water resources management in these 
large-scale models and focus on water quantity rather than water quality. We note that while historically the effects of water management have largely been neglected in LSMs and GHMs, there has been increasing interest in recent years in their inclusion and a common first step is to estimate the demand for water, in particular associated with irrigation (see Nazemi and Wheater, 2015). However, in practice water resource systems are often complex, and associated infrastructure may have competing functional requirements and constraints (e.g., flood protection, water supply, environmental flows), exacerbated during drought. In this paper, we turn to the issues around water supply and allocation and associated representations in large-scale models.

Major implications are associated with water allocation from surface-water and groundwater sources. For instance, large dams and reservoirs can significantly modify downstream streamflow characteristics (e.g., Vörösmarty et al., 1997, 2003; Oki and Kanae, 2006; Wisser et al., 2010; Tang et al., 2010; Tebakari et al., 2012; Lehner and Grill, 2013; Lai et al., 2014; Haddeland et al., 2014), with large regional variability (see, e.g., Pokhrel et al., 2012a). Considering that almost all major river systems in the Northern Hemisphere (except for the arctic and subarctic regions) are dammed (e.g., Meybeck, 2003; Nilsson et al., 2005), it can be argued that accurate simulation of continental and global runoff is impossible without considering the effects of reservoirs. Such hydrologic impacts and associated environmental consequences can be studied through offline LSMs or GHMs. There are, however, important land-surface implications associated with reservoir operation that require online simulations. For instance, it has also been argued that large dams can have important footprints on surface energy (Hossain et al., 2012), with associated effects on land-surface boundary conditions and potential interactions with local and regional climate (MacKay et al., 2009). To understand these effects, online LSMs, i.e., coupled with climate models, are required to provide quantitative knowledge of the extent of such impacts in time and space.

Groundwater resources have also been extensively perturbed during the "Anthropocene". Every year, a large amount of groundwater is pumped to the land surface for both irrigative and non-irrigative purposes (e.g., Zektser and Lorne, 2004; Siebert et al., 2010). Such extraction has already caused large groundwater depletion in some areas (Rodell et al., 2007, 2009; Gleeson et al., 2010, 2012) and changed the surface water balance due to return flows from demand locations to river systems and ultimately to oceans (e.g., Lettenmaier and Milly, 2009; Wada et al., 2010; Pokhrel et al., 2012b; Döll et al., 2014). In parallel, a considerable proportion of the surface water diverted into irrigated areas may recharge groundwater (Döll et al., 2012). From a broader perspective, groundwater aquifers (particularly shallow groundwater) can also be an important control on soil moisture and wetlands, and thus influence atmospheric surface boundary conditions (e.g., Maxwell et al., 2007, 2011;
Fan and Miguez-Macho, 2011; Dadson et al., 2013). These online effects are widely unquantified at the global scale, as the sub-surface processes below the root zone have been generally assumed to be disconnected from the atmosphere (see Taylor et al., 2013).

In addition, representing water allocation practice in largescale models is urgently required to address various emerging water security concerns including (but not limited to) human water supply (e.g., Postel et al., 1996), ecosystem health (e.g., Vörösmarty et al., 2010), sedimentation (e.g., Syvitsky et al., 2005) and water quality (e.g., Skliris and Lascaratos, 2004). These latter areas are beyond the scope of this paper, but highlight the need to represent human water allocation in large-scale models for regional and global impact assessments. For instance, the most densely populated parts of the globe suffer from extremely fragile water supply conditions (e.g., Grey et al., 2013; Falkenmark, 2013; Nazemi and Wheater, 2015) and this will be amplified under future climate change and population growth (e.g., Arnell, 2004; Wada et al., 2013; Rosenzweig et al., 2014; Schiermeier, 2014; Haddeland et al., 2014). While population growth directly affects water demand, indirect effects include changing land and water management, with associated impacts on the aquatic environment. Similarly, climate change is expected to perturb both water demand and supply, as it also results in greater seasonal and inter-annual variability with increase in the risk of extreme conditions (e.g., Dankers et al., 2014; Prudhomme et al., 2014). Looking to the future, Yoshikawa et al. (2014) argued that current sources can only account for $74 \%$ of the global net irrigation requirements of the 2050s and supply-demand imbalance will cause a major increase in global water scarcity (Alcamo et al., 2007; Hanasaki et al., 2008a, b, 2013a, b; Schewe et al., 2014). In water-scarce conditions, competition for water resources becomes increasingly important and the details of water allocation practice play a key role in the spatial and temporal distribution of water stress. These issues necessitate adaptation strategies to mitigate the effects of water stress and extreme conditions; large-scale models are, therefore, required to assess the effects of various global changes and to examine the impact of alternative management strategies.

Representation of water allocation practice introduces a set of issues associated with management and societal preferences, local and regional differences in decision making, complexity of water resources systems (particularly at larger scales), as well as lack of data support. At local and basin scales, water allocation practice is mainly defined as an optimization problem, in which the aim is to minimize the adverse effects of water shortage and/or to maximize the economic benefits of the water resource system. The advent of search algorithms such as linear programming (Dantzig, 1965), dynamic programming (Bellman, 1952) and genetic algorithms (Goldberg, 1989) has resulted in a wide variety of operational models for water resource management at small basin scale (e.g., Rani and Moreira, 2010; Hossain and El- 
shafie, 2013; see Revelle et al. (1969) for the early developments). These small-scale water allocation models, however, typically do not include processes related to water supply and demand and receive these variables as prescribed inputs. Moreover, small-scale operational models often require detailed information about policy constraints and operational management. This information is not generally available over larger regions and at the global scale. Even if all related information were to be available, the level of complexity within small-scale operational models cannot be supported globally due to high dimensionality in decision variables and computational burdens. These restrictions have resulted in the progressive development of macro-scale algorithms to represent water allocation practice and competition among demands at regional and global scales.

The main objective of this paper is to overview the current literature and to identify the state of available methods and applications for large-scale representations of water supply and allocation in LSMs and GHMs, with relevance to both Earth system and large-scale hydrological modeling. Section 2 addresses the representation of surface-water and groundwater sources. Section 3 discusses the linkage between available sources and prescribed demands (see Nazemi and Wheater, 2015) through macro-scale allocation algorithms. Section 4 reviews current large-scale modeling applications and discusses the quality of available simulations. Section 5 merges the findings of Nazemi and Wheater (2015) with those obtained in Sects. 2 to 4, and highlights current gaps and opportunities from an integrated water resources, hydrology and land-surface modeling perspective. This is finalized by suggesting a systematic framework for model development and uncertainty assessment to guide future efforts in inclusion of water resource management in large-scale models. Section 6 closes our survey and provides some concluding remarks.

\section{Available representations of water sources in large-scale models}

\subsection{Lakes and reservoirs}

Natural lakes and man-made reservoirs cover more than $2 \%$ of the global land surface area except for Antarctica and glaciated Greenland (Lehner and Döll, 2004). Lakes and reservoirs are important water sources due to their ability to store and release surface water for human demand. While natural lakes have been historically an important water source for human civilization, man-made reservoirs have been mainly constructed over the last 50 years. Currently, there are more than 16 million reservoirs worldwide (Lehner et al., 2011), retaining around $20 \%$ of the annual runoff and $10 \%$ of the total volume of the world's freshwater lakes (Gleick, 2000; Meybeck, 2003; Wood et al., 2011). This makes an important global water resource: Yoshikawa et al. (2014) es- timated that reservoirs allocated $500 \mathrm{~km}^{3}$ just for irrigation during the year 2000, worldwide.

From the large-scale modeling perspective, lakes and reservoirs introduce heterogeneity into land-surface parameterizations, with both offline and online implications. To represent these open water bodies, first they should be identified at the grid and sub-grid scales. The availability of basic data for larger lakes and reservoirs is relatively good (see Lehner and Döll, 2004, for a comprehensive list of data sources). For instance, the Global Lakes and Wetlands Database (GLWD; http://www.worldwildlife.org/pages/ global-lakes-and-wetlands-database) includes more than 250000 lakes globally. In addition, the International Commission of Large Dams (ICOLD; http://www.icold-cigb.net/) and Global Reservoir and Dam (GRanD; http: //www.gwsp.org/products/grand-database.html) databases contain information about the location, purpose and capacity of 33000 and 7000 large dams, worldwide. However, to estimate evaporation, as well as storage and release, more specific physical characteristics, such as storage-area-depth relationships, are required. These data are generally not available and parametric relationships have been used to approximate these properties based on various assumptions (e.g., Takeuchi, 1997; Liebe et al., 2005). Nonetheless, at this stage of model development, reservoir simulations cannot be directly verified, due to the lack of observations of reservoir level and storage (Gao et al., 2012). These data limitations may be largely solved in the relatively near future by upcoming satellite missions - see the discussion of Sect. 5.3.

Depending on their size, lakes and reservoirs can be represented either within channel or sub-grid routing components of host large-scale models. While larger lakes and reservoirs are normally represented within the river routing component and regulate the channel streamflow, smaller bodies are mainly considered within sub-grid parameterizations as an additional pond (e.g., Döll et al., 2003; Wisser et al., 2010). Ideally, natural lakes and reservoirs should differ in their representation due to human management. If human management is neglected, reservoir releases can be represented similar to natural lakes using simple parametric equations that link the reservoir release to reservoir storage (or level) - see e.g., Meigh et al. (1999), Döll et al. (2003), Pietroniro et al. (2007) and Rost et al. (2008). Lake algorithms, however, have had limited success in highly regulated basins. This is rather intuitive: for natural lakes, the dynamics of lake storage (and hence discharge) are regulated by climate and inflow variability, whereas the dynamics of reservoir discharge (and hence storage) are mainly controlled by pressures of downstream demands and management decisions. Moreover, reservoirs are often multi-functional and deal with competing demands with varying priority in time; therefore, simple lake routing algorithms are unable to fully describe reservoir functionality. Alternatively, macro-scale algorithms for reservoir operation have been suggested, which attempt to 
link reservoir releases to inflows, storage and prescribed human demands considering water allocation objectives - see Sect. 3.3.

Considering online implications, the effects of dams on near-surface energy and moisture conditions and hence landatmospheric feedbacks can be important for large reservoirs (Hossain et al., 2012). Addressing this issue using coupled LSMs is currently a major gap in the literature and presents a challenging problem at the grid scale, since the impact of dams on the local climate can be masked by regional climate variability and surrounding land cover (e.g., Zhao and Shepherd, 2012).

\subsection{Streamflow diversions and inter-basin water transfers}

Streamflow diversions of any magnitude require dams or barrages. At smaller scales, these include within-basin water transfers from local streams to nearby demands. In-basin diversions are often represented in large-scale models by instantaneous abstractions (e.g., Hanaski et al., 2008a, 2010; Döll et al., 2009). Hydrologic routing can be alternatively considered for improved representation (e.g., Wisser et al., 2010). It should be noted that a proportion of the diverted flow normally returns to the river systems. Heuristic algorithms have been advised to mimic the mechanism of diversion based on returning the excess water to the river with some lag. Biemans et al. (2011) for instance represented the dynamics of diverted/return flows for irrigated areas by making water available for consumption for 5 days; if unused, it is released back to the river. This can have important implications for differentiating between the actual use and total withdrawals, in the case where water is over-allocated.

Inter-basin water transfers normally involve major infrastructure and can significantly perturb the regional streamflow regime. For instance, proposed south to north water transfer schemes in China (see Liu and Zheng, 2002; Liu and Yang, 2012) would divert 44.8 billion $\mathrm{m}^{3}$ of water annually (http://www.internationalrivers.org/). The associated hydrological impacts are estimated to be as or more significant than land-use and/or land-cover changes (J. Liu et al., 2013). Inter-basin water transfer can be adequately represented by hydrologic routing. Examples are available for some regional applications (e.g., Nakayama and Shankman, 2013a, b; Ye et al., 2013); however, efforts to represent long-distance diversions at the global scale are limited. This is mainly due to data issues regarding the location and specification of diversion channels globally. This could be largely resolved in future due to improvements in remote sensing observations see the discussion of Sect. 5.3.

\subsection{Groundwater}

Even large-scale models with detailed water resource management schemes have limited representation of groundwa- ter availability (see Table 1), largely due to the limitations in data related to groundwater storage, withdrawals and subsurface properties as well as computational difficulties. There have been some efforts to include groundwater in LSMs to describe the aquifer dynamics, land-atmospheric feedbacks and watershed responses, mainly at basin and small regional scales (e.g., Maxwell and Miller, 2005; Maxwell et al., 2007, 2011; Kollet and Maxwell, 2008; Ferguson and Maxwell, 2010). These studies consider a physically based groundwater store, which can be updated at each modeling time step using a 3-D representation of groundwater movement, and linked to land-surface calculations through soil moisture dynamics. Such representations are computationally expensive and limited at the global scale, since temporal and spatial domains should be finely gridded for accurate representations of groundwater movement and soil-moisture interactions, particularly in online studies. To the best of our knowledge, no online study characterizing the feedback effects between groundwater management and climate is available at the global scale. Offline representation of groundwater management has mainly been performed in the context of GHMs and involves estimation of available groundwater storage, sub-grid groundwater recharge and groundwater withdrawals. In this section, we focus on groundwater availability and recharge and leave the discussion related to groundwater withdrawals to Sect. 3.2.

In current representations, often groundwater availability in general, or the nonrenewable and nonlocal blue water (NNBW) in particular, is assumed as an unlimited local source (e.g., Rost et al., 2008; Biemans et al., 2011; Pokhrel et al., 2012a, b). NNBW is a technical term defined as an "imaginary" source that implicitly accounts for nonrenewable fossil groundwater or other water sources that are not explicitly represented in the model. This can cause major uncertainties in estimation of actual withdrawals (see Sect. 3.2). Efforts have been made to improve this assumption. For instance, Strzepek et al. (2012) bounded groundwater availability by considering a threshold for groundwater allocation. Wada et al. (2014) proposed a conceptual linear groundwater reservoir, parameterized globally based on lithology and topography, to estimate the groundwater availability at the grid scale using the baseflow as a proxy. Although this conceptual representation provides an efficient scheme for global simulations, it ignores the baseflow reduction due to groundwater depletion. In a more recent attempt, Döll et al. (2014) continuously simulated the daily groundwater storage using the difference between groundwater recharge and the sum of baseflow and net groundwater abstraction, with base flow declining with decreasing groundwater storage. Both algorithms, however, do not consider inter-grid lateral groundwater movement, which can have an important impact on water availability across various scales. Although lateral groundwater movement is widely studied in aquifer studies at smaller basin and regional scales (e.g., Ye et al., 2013), 


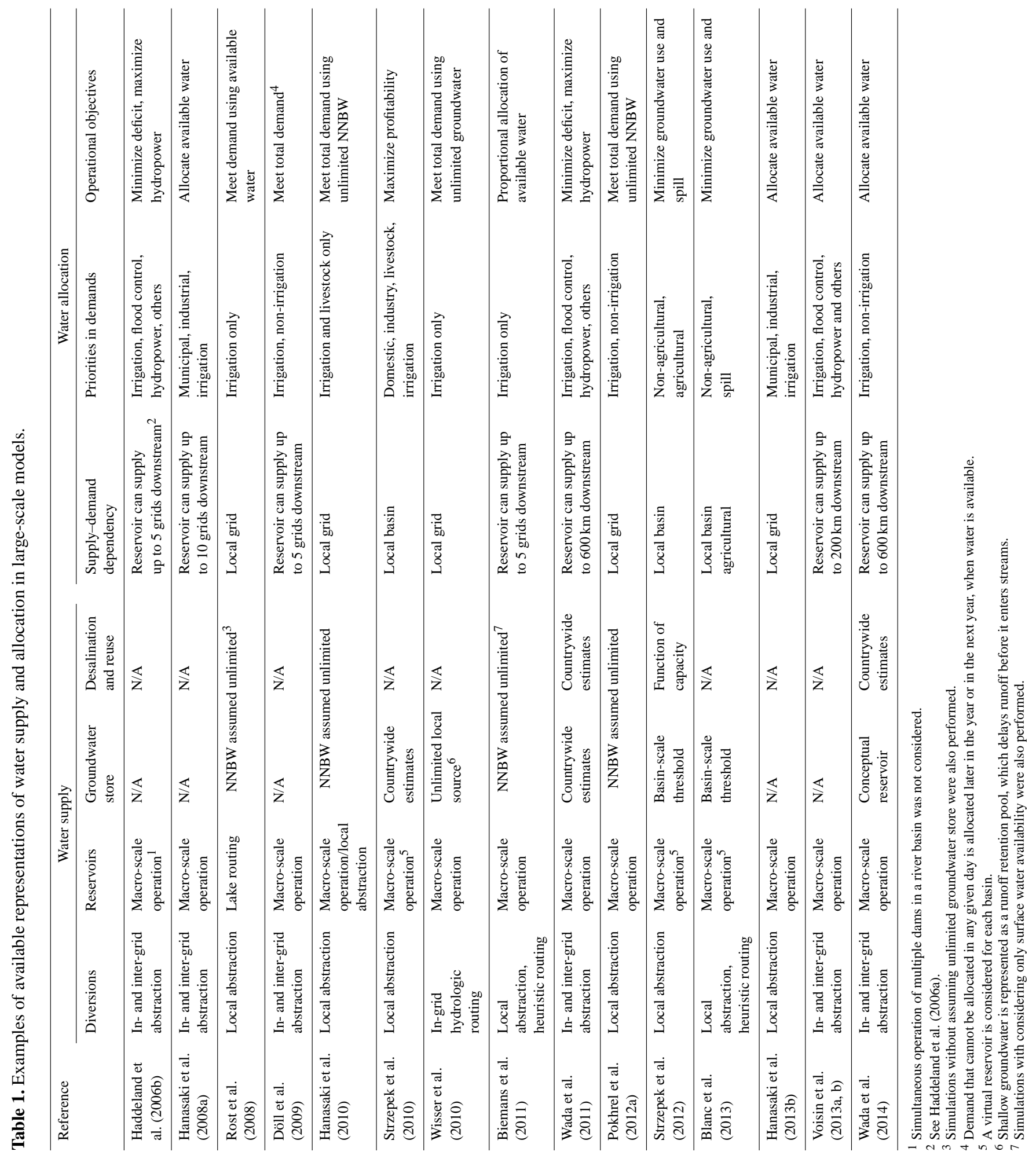


it is currently a key missing process representation at larger regional and global scales (Taylor et al., 2013).

Groundwater recharge includes the movement of water from the unsaturated soil zone to a saturated groundwater body. There are a number of approaches to represent the vertical water movement in large-scale models, including heuristic methods (e.g., Döll et al., 2003), conceptual "leaky buckets" (e.g., Wada et al., 2010), or numerical solutions of the physically based Richards' equation (Best et al., 2011; D. B. Clark et al., 2011). These approaches are based on various assumptions and are subject to large uncertainties. Heuristic schemes relate the recharge rate to surface runoff, using a set of parameters based on catchment, soil and aquifer characteristics. These representations are often simplistic and may result in large estimation errors, particularly in arid and semi-arid regions (Polcher et al., 2011). Conceptual approaches widely assume a steady-state condition and use the unsaturated hydraulic conductivity to represent groundwater recharge with or without considering capillary rise (van Beek and Bierkens, 2008; Wada et al., 2010, 2014; van Beek et al., 2011; Ye et al., 2013). In a global study, Wada et al. (2012) used this approach to account for additional recharge from irrigated lands based on the unsaturated hydraulic conductivity at field capacity. This can be important for representing the excess water diverted from both surface and groundwater sources. Although conceptual representations are efficient for large-scale studies, still limitations remain in these schemes due to large heterogeneities in soil characteristics, a common assumption of steady-state recharge rate, as well as the inherent uncertainty associated with soil hydraulic properties. The physically based approaches remove the steady-state assumption; nonetheless as discussed above, they require a detailed numerical scheme for solving a highly non-linear partial differential equation. This is subject to various computational difficulties at larger scales, and invariably there is a gap between the scale for which Richards' equation was developed and the scale at which it is implemented in large-scale groundwater and hydrologic models (Beven, 2006a; Gentine et al., 2012).

\subsection{Desalination and water reuse}

Water reuse and desalination are currently minor water resources at the global scale and have been widely ignored in large-scale models. Nonetheless, it should be noted that these water sources have local relevance and are important in several water-limited regions (Wade Miller, 2006; Pokhrel et al., 2012a). Wada et al. (2011) estimated that annual desalinated water use is around $15 \mathrm{~km}^{3}$ globally, of which Kazakhstan uses $10 \%$ of the total volume. Desalinated water availability can be estimated using a bottom-up approach based on the information available about treatment and water reuse capacity at the grid scale (Strzepek et al., 2012). These data, however, are limited and uncertain globally. Alternatively, topdown approaches try to downscale countrywide data. Wada et al. (2011, 2014), for instance, downscaled the countrywide data on water reuse and desalination using a gridded population map. Considering that water reuse and desalination will likely be more important in future due to increased water scarcity at the global scale, we suggest more effort in representing these sources, including data collection to support future algorithm developments - see Sect. 5.3.

\section{Available representations of water allocation in large-scale models}

Water allocation distributes the available water sources among competing demands and should typically include a set of management decisions to systematically (1) link the prescribed demands to available sources of water; (2) determine allocation objectives as well as priorities in case of water shortage; and (3) withdraw the available water based on allocation objectives and management constraints. At this stage of model development, there are limited examples for representation of water allocation at larger scales. These studies are offline and have multiple sources of uncertainty. Table 1 summarizes some examples from the recent literature. In this section, we briefly discuss the main requirements and available algorithms for representing water allocation in largescale models.

\subsection{Main requirements}

The first basic requirement is to identify which sources are available to supply the water demands within each computational grid. The majority of current allocation schemes assume that grid-based demands can be supplied from the sources available within the local grid. This assumption is intuitive and easy to implement; however, it naturally ignores long-distance water transfers. Various modifications have been proposed to overcome this limitation. Relative elevation and travel time of water from source to demand have been used to condition demands to available sources upstream. For example, Hanaskai et al. (2006) assumed that large reservoirs can potentially supply downstream demands that are located within $1100 \mathrm{~km}$ (based on a travel time of 1 month). Similarly, Wada et al. (2011) considered a criterion of approximately $600 \mathrm{~km}$ and Biemans et al. (2011) $250 \mathrm{~km}$. These rules are evidently simplistic but can be easily implemented. They also generally assume steady-state conditions, so that the allocated water can be simply abstracted from the source and added at the demand location at the same time step. Alternatively, routing schemes can provide a more accurate basis for representing the water delivery and avoid this limitation - see the discussion of Sect. 5.5.

The second important issue is to determine objectives of and priorities for water allocation, particularly during shortage. In the absence of access to local operating rules, this requires defining a set of generic rules to assign the rela- 
tive preference of each demand and to define the purpose of water allocation. Both irrigative (e.g., Rost et al., 2008; Döll et al., 2009; Wada et al., 2014) and non-irrigative demands (e.g., Hanasaki et al., 2008a; Strzepek et al., 2010, 2012; Blanc et al., 2013) have been given the highest priority. In cases where multiple demands with the same priority are derived from a unique source of water, the deficit is typically shared proportionately to the demands (e.g., Biemans et al., 2011). Based on priorities and assumptions made regarding water availability, several allocation objectives have been used (see Table 1). It should be noted that water resource management is commonly multi-purpose, and allocation objectives and priorities can change within a typical operational year. For example, many reservoirs are designed for two conflicting objectives, i.e., irrigation supply and flood control. To account for this, Voisin et al. (2013a) developed flood control storage targets to complement the irrigation release targets. They used rule curves to drop the reservoir storages before snowmelt starts while maintaining the storage in the reservoir to provide releases for irrigation, water supply and hydropower in the remaining part of the year. They showed that this modification can improve the simulation of regulated flow and maintain the spatiotemporal consistency of reservoir levels - see Voisin et al. (2013a) for more details.

Finally, allocation algorithms are required to estimate groundwater abstractions and reservoir releases at each simulation time step based on allocation objectives and priorities. Groundwater abstraction algorithms are generally limited, due to significant gaps in information about groundwater availability and actual groundwater withdrawals at the global scale. Although current data availability for lakes and reservoirs storages is also poor, runoff data are relatively available regionally and globally, which can be used for algorithm development and performance assessment through comparison of simulated and observed discharges downstream of reservoirs. Apart from local or national data, data of the Global Runoff Data Centre (GRDC; http://www.bafg.de/GRDC/) have been widely used for validation of macro-scale reservoir operation algorithms.

\subsection{Grid-based groundwater abstractions}

Groundwater abstractions include both sustainable (renewable) and unsustainable (non-renewable) water uses. While sustainability of groundwater withdrawals is a complex issue, in particular related to environmental impacts of abstraction, the distinction between these for large-scale applications is generally based on the grid-based groundwater recharge, as any abstraction exceeding recharge rate results in groundwater depletion and, therefore, can be considered as unsustainable. So far, groundwater withdrawals have been estimated through either bottom-up or top-down algorithms, both subject to large uncertainty.
In bottom-up procedures, the groundwater abstraction is identified using grid-based estimates of surface and groundwater availability as well as the water demand. If the groundwater and/or NNBW is considered as an infinite sources (Rost et al., 2008; Hanasaki et al., 2010; Wisser et al., 2010; Pokhrel et al., 2012a, b), then the groundwater or NNBW abstraction is equal to estimated demand minus estimated surface water availability at the grid scale. In this case, priorities are not inherently considered; however NNBW has the advantage that it explicitly accounts for the water that should come to the system from outside the modeled domain. If the groundwater availability is bounded at the grid or basin scale, then the maximum groundwater withdrawal cannot exceed the local groundwater availability (e.g., Strzepek et al., 2012; Wada et al., 2014); however, errors in estimations of surface water availability and water demands can still directly propagate into estimation of groundwater withdrawals.

Top-down approaches are based on using recorded regional groundwater withdrawals or downscaling national groundwater abstractions data to finer spatial scales. Siebert et al. (2010) created a global data set for irrigation water supply from groundwater abstractions based on FAO-AQUASTAT (http://www.fao.org/nr/water/aquastat/ main/index.stm) and other census and sub-national data. In an another effort, Wada et al. $(2010,2012)$ used the data of the International Groundwater Resources Assessment Center (IGRAC; http://www.igrac.net) to estimate the countrywide groundwater use for year 2000. These estimates were further downscaled to $0.5^{\circ} \times 0.5^{\circ}$ grids, based on a global map of yearly total water demand. In a countywide study, Blanc et al. (2013) used the groundwater withdrawal data of the USGS for the year 2005 (USGS, 2011) and repeated the data for every year of simulation. These approaches are also limited by the fact that the actual groundwater pumping might be considerably more than the recorded data (e.g., Foster and Loucks, 2006; Wada et al., 2012) and groundwater withdrawals can have considerable inter-annual variability. Current and upcoming remote sensing technologies can address some of the issues around groundwater data availability - see Sect. 5.3.

\subsection{Macro-scale reservoir operation}

Current macro-scale reservoir operation algorithms are designed for offline applications and included in large-scale models for characterizing the impacts of reservoirs on terrestrial water storage, runoff and water supply. These algorithms can be roughly divided into two general categories based on either simulating the reservoir release using a set of prescribed operational rules or using search algorithms to find optimal reservoir release. In brief, simulation-based schemes are based on a set of functional rules that use initial storage as well as inflows and demand pressure during a typical operational period to simulate releases during the operational period. In contrast, optimization-based algorithms search for 
optimal releases at each time step given an ideal storage at the end of the operational year, storage at the beginning of the year and expected inflows and demands during the year. Naturally, optimization-based algorithms are more computationally expensive; nonetheless, they are more suitable for evaluating competition among water demands and effects of policy change, due to the ability to explicitly include multiple allocation objectives to guide the search for optimal releases. In contrast, simulation-based algorithms are more efficient and can be potentially modified to support online simulations - see Sect. 5.4. Table 2 summarizes some representative examples from the current literature.

\subsubsection{Available simulation-based algorithms}

Current simulation-based algorithms are heavily influenced by the work of Hanasaki et al. (2006), which was initially proposed for global routing models but extended to GHMs (Hanasaki et al., 2008a, 2010) and LSMs (Pokhrel et al., 2012a, b). The algorithm distinguishes between operational rules for irrigation and non-irrigation purposes. The algorithm also accounts for both inter-annual variability and seasonality in reservoir releases. In simple terms, the total release in a typical operational year is first determined based on the reservoir capacity, initial storage and the annual mean natural inflow to the reservoir. Second, the monthly fluctuations in the reservoir release are parameterized based on annual mean natural inflow, mean annual demand and the prescribed monthly demand. Note that demands are considered as total water withdrawals rather than consumptive uses. Finally, monthly fluctuations are corrected based on interannual variability in total reservoir releases (estimated during the first step) to provide actual monthly reservoir releases. The correction, depending on the purpose and size of reservoir, is based on the ratio of initial reservoir storage to total capacity, the ratio of reservoir capacity to annual mean inflow, and/or the monthly mean natural inflows to the reservoir - see Hanasaki et al. (2006) for related formulations.

The Hanasaki et al. algorithm has been widely used in the recent literature as it provides a generic and flexible framework to represent reservoir operation. Döll et al. (2009) implemented this algorithm to represent operation of large reservoirs within the framework of WaterGAP (Alcamo et al., 2003). They considered some modifications to accommodate losses from the reservoir and to characterize the dynamics of demand pressure on reservoirs based on consumptive uses rather than total water withdrawals. Biemans et al. (2011) modified the algorithm of Hanasaki et al. (2006) by extracting the reservoir releases using annual and monthly mean regulated inflows (rather than corresponding natural flows), limiting the demand pressure only to irrigation and changing the release rules during high-demand periods. These modifications were further added to the Joint UK Land Environment Simulator (JULES; Best et al., 2011; D. B. Clark et al., 2011) for offline simulations (Polcher et al., 2011). Voisin et al. (2013a) made a regional intercomparison between various simulation-based algorithms for the Columbia River basin and concluded that deriving releases based on withdrawals rather than consumptive uses results in improved simulations of downstream flows. They also indicated that the choice of natural or regulated inflows depends on the severity of the demand pressure and water allocation: if the overall water demand is high with respect to mean annual inflow, it would be better to drive the algorithm with mean monthly regulated inflow; otherwise it is better to use the natural flow, due to large uncertainties associated with water demand estimates and, therefore, regulated flows. Although this study is limited to one region, it provided an assessment of uncertainties in estimating the reservoir releases due to uncertainties in estimating both inflows and water demand - see the discussion of Sect. 4.

Existing simulation-based schemes are not limited to the above algorithms. Efforts have been made to simulate the reservoir releases using parametric functions, in which the parameters can be calibrated using observed downstream flows. For example, Wisser et al. (2010) advised a set of functional rules to parameterize the release from large reservoirs using the actual inflow and the long-term mean inflow to the reservoirs. More recently, Wu and Chen (2012) proposed a new algorithm by explicit consideration of operational rule curves, locally specified for each reservoir. In brief, rule curves are a set of pre-defined reservoir levels that divide the total reservoir capacity into different storage zones. These storage zones can be further associated with demands conditioned on the reservoir using various assumptions. The algorithm considers the reservoir operation at a given day as a deviation from mean releases at that day and represents this by a weighted sum of individual variations as the result of allocation for each individual water demand. Demand-specific allocations can be therefore characterized based on rule curves, the available storage, total capacity as well as the history of inflow to the reservoir. Accordingly the total release at any given day can be defined as a parametric function, in which the parameters can be tuned using observed downstream flows. Although they noted that the operational parameters are inherently time-varying, as the purpose of dam can change with time, a systematic scheme for dealing with non-stationary parametric estimation has not been provided. This remains for future efforts - see Sect. 5.4.

\subsubsection{Available optimization-based algorithms}

Optimization-based schemes were initially proposed by Haddeland et al. (2006a) and implemented further in Haddeland et al. (2006b, 2007). These algorithms are heavily inspired by small-scale reservoir operation algorithms within the engineering literature, particularly dynamic programming (see Voisin et al., 2013a), and strongly rely on estimates of expected inflow and demand. Therefore, they are not suitable for online simulations; however, they can be valuable for in- 
Table 2. Representative examples of available macro-scale reservoir operation algorithms implemented in large-scale models.

\begin{tabular}{|c|c|c|c|c|c|}
\hline Reference & Host model & $\begin{array}{l}\text { Routing } \\
\text { algorithm }\end{array}$ & $\begin{array}{l}\text { Type of } \\
\text { operation }\end{array}$ & Reservoir data & Validation discharge data \\
\hline $\begin{array}{l}\text { Hanasaki et } \\
\text { al. (2006) }\end{array}$ & N/A & $\begin{array}{l}\text { TRIP (Oki and } \\
\text { Sud, 1998) }\end{array}$ & $\begin{array}{l}\text { Simulation- } \\
\text { based }\end{array}$ & $\begin{array}{l}\text { WRD98 } \\
\text { (ICOLD) }\end{array}$ & $\begin{array}{l}\text { GSWP (Dirmeyer et al., 1999; } \\
\text { Oki et al., 2001) }\end{array}$ \\
\hline $\begin{array}{l}\text { Haddeland et } \\
\text { al. (2006a, b, } \\
\text { 2007) }\end{array}$ & $\begin{array}{l}\text { VIC (Liang et } \\
\text { al., 1994) }\end{array}$ & $\begin{array}{l}\text { Linearized } \\
\text { Saint-Venant } \\
\text { (Lohmann et al., } \\
\text { 1996, 1998) }\end{array}$ & $\begin{array}{l}\text { Optimization- } \\
\text { based }\end{array}$ & $\begin{array}{l}\text { ICOLD; } \\
\text { Vörösmarty et al. } \\
(1997,2003)\end{array}$ & $\begin{array}{l}\text { USGS (http://waterdata.usgs.gov) } \\
\text { USBR (http://www.usbr.gov) } \\
\text { GRDC } \\
\text { (http://www.bafg.de/GRDC/) }\end{array}$ \\
\hline $\begin{array}{l}\text { Adam et al. } \\
(2007)\end{array}$ & $\begin{array}{l}\text { VIC (Liang et } \\
\text { al., 1994) }\end{array}$ & $\begin{array}{l}\text { Unit } \\
\text { hydrograph and } \\
\text { Linearized } \\
\text { Saint-Venant } \\
\text { (Lohmann et al., } \\
\text { 1996, 1998) }\end{array}$ & $\begin{array}{l}\text { Optimization- } \\
\text { based }\end{array}$ & $\begin{array}{l}\text { ICOLD; } \\
\text { Vörösmarty et al. } \\
(1997,2003)\end{array}$ & Adam and Lettenmaier (2008) \\
\hline $\begin{array}{l}\text { Hanasaki et } \\
\text { al. }(2008 a)\end{array}$ & $\begin{array}{l}\text { H08 (Hanasaki } \\
\text { et al., 2008a, b) }\end{array}$ & $\begin{array}{l}\text { TRIP (Oki and } \\
\text { Sud, 1998) }\end{array}$ & $\begin{array}{l}\text { Simulation- } \\
\text { based }\end{array}$ & $\begin{array}{l}\text { WRD98 } \\
\text { (ICOLD) }\end{array}$ & $\begin{array}{l}\text { GRDC } \\
\text { (http://www.bafg.de/GRDC/) }\end{array}$ \\
\hline $\begin{array}{l}\text { Döll et al. } \\
(2009)\end{array}$ & $\begin{array}{l}\text { WaterGAP } \\
\text { (Alcamo et al., } \\
\text { 2003) }\end{array}$ & $\begin{array}{l}\text { HBV } \\
\text { (Bergström and } \\
\text { Singh, 1995) }\end{array}$ & $\begin{array}{l}\text { Simulation- } \\
\text { based }\end{array}$ & $\begin{array}{l}\text { GRanD (Lehner } \\
\text { et al., 2008) }\end{array}$ & $\begin{array}{l}\text { GRDC } \\
\text { (http://www.bafg.de/GRDC/) }\end{array}$ \\
\hline $\begin{array}{l}\text { Wisser et al. } \\
(2010)\end{array}$ & $\begin{array}{l}\text { WBMplus } \\
\text { (Vörösmarty et } \\
\text { al., 1998) }\end{array}$ & $\begin{array}{l}\text { Muskingum- } \\
\text { Cunge (Ponce } \\
\text { and Changanti, } \\
\text { 1994) }\end{array}$ & $\begin{array}{l}\text { Simulation- } \\
\text { based }\end{array}$ & ICOLD & $\begin{array}{l}\text { UNH-GRDC (Fekete et al., 1999, } \\
\text { 2002) }\end{array}$ \\
\hline $\begin{array}{l}\text { Biemans et al. } \\
(2011)\end{array}$ & $\begin{array}{l}\text { LPJmL (Gerten } \\
\text { et al., 2004; } \\
\text { Rost et al., } \\
\text { 2008) }\end{array}$ & $\begin{array}{l}\text { Linear reservoir } \\
\text { model (Huggins } \\
\text { and Burney, } \\
\text { 1982) }\end{array}$ & $\begin{array}{l}\text { Optimization- } \\
\text { based }\end{array}$ & $\begin{array}{l}\text { GRanD (Lehner } \\
\text { et al., 2011) }\end{array}$ & $\begin{array}{l}\text { GRDC } \\
\text { (http://www.bafg.de/GRDC/) }\end{array}$ \\
\hline $\begin{array}{l}\text { Van Beek et } \\
\text { al. }(2011)\end{array}$ & $\begin{array}{l}\text { PCR-GLOBWB } \\
\text { (van Beek and } \\
\text { Bierkens, 2009) }\end{array}$ & $\begin{array}{l}\text { Kinematic } \\
\text { Saint-Venant } \\
\text { (Chow et al., } \\
\text { 1998) }\end{array}$ & $\begin{array}{l}\text { Optimization- } \\
\text { based }\end{array}$ & $\begin{array}{l}\text { GLWD1 (Lehner } \\
\text { and Döll, 2004) }\end{array}$ & $\begin{array}{l}\text { GRDC } \\
\text { (http://www.bafg.de/GRDC/) }\end{array}$ \\
\hline $\begin{array}{l}\text { Wu and Chen } \\
(2012)\end{array}$ & $\begin{array}{l}\text { SWAT (Arnold } \\
\text { et al., 1998) }\end{array}$ & $\begin{array}{l}\text { SWAT (Arnold } \\
\text { et al., 1998) }\end{array}$ & $\begin{array}{l}\text { Simulation- } \\
\text { based }\end{array}$ & Wu et al. (2007) & Chen and $\mathrm{Wu}(2008)^{*}$ \\
\hline $\begin{array}{l}\text { Pokhrel et al. } \\
(2012 \mathrm{a})\end{array}$ & $\begin{array}{l}\text { MASTIRO } \\
\text { (Takata et al., } \\
\text { 2003) }\end{array}$ & $\begin{array}{l}\text { TRIP (Oki et } \\
\text { al., 2001) }\end{array}$ & $\begin{array}{l}\text { Simulation- } \\
\text { based }\end{array}$ & $\begin{array}{l}\text { WRD98 } \\
\text { (ICOLD) }\end{array}$ & $\begin{array}{l}\text { GRDC } \\
\text { (http://www.bafg.de/GRDC/) }\end{array}$ \\
\hline $\begin{array}{l}\text { Voisin et al. } \\
\text { (2013a) }\end{array}$ & $\begin{array}{l}\text { VIC (Liang et } \\
\text { al., 1994) }\end{array}$ & $\begin{array}{l}\text { MOSART (Li et } \\
\text { al., 2013; Tesfa } \\
\text { et al., 2014) }\end{array}$ & $\begin{array}{l}\text { Simulation- } \\
\text { based }\end{array}$ & $\begin{array}{l}\text { GRanD (Lehner } \\
\text { et al., 2011) }\end{array}$ & $\begin{array}{l}\text { USGS (http://waterdata.usgs.gov) } \\
\text { USBR (http://www.usbr.gov) } \\
\text { GRDC } \\
\text { (http://www.bafg.de/GRDC/) }\end{array}$ \\
\hline $\begin{array}{l}\text { Voisin et al. } \\
(2013 b)\end{array}$ & $\begin{array}{l}\text { SCLM (Li et } \\
\text { al., 2011; } \\
\text { Lawrence et al., } \\
\text { 2011) }\end{array}$ & $\begin{array}{l}\text { MOSART (Li et } \\
\text { al., 2013; Tesfa } \\
\text { et al. 2014) }\end{array}$ & $\begin{array}{l}\text { Simulation- } \\
\text { based }\end{array}$ & $\begin{array}{l}\text { GRanD (Lehner } \\
\text { et al., 2011) }\end{array}$ & $\begin{array}{l}\text { USGS (http://waterdata.usgs.gov) } \\
\text { USBR (http://www.usbr.gov) } \\
\text { GRDC } \\
\text { (http://www.bafg.de/GRDC/) }\end{array}$ \\
\hline
\end{tabular}

* Discharge data used for calibration as well. 
tegrated impact assessment over large grids and/or assessment regions in offline mode (see, e.g., Strzepek et al., 2010, 2012; Blanc et al., 2013). In brief, the calculation starts by targeting the reservoir storage at the end of a typical operational year based on expected demands. Then, the minimum release at each daily time step is defined based on the expected streamflow at the dam's location to maintain a minimum flow requirement downstream of the reservoir. Accordingly, the maximum allowable daily release is determined based on simulated daily inflow, minimum release, reservoir storage at the beginning of the operational year and the targeted storage at the end of the year. Minimum and maximum releases introduce a feasible release range, where a search algorithm can be used to find the optimal monthly releases that provide the minimum deficit during the year and the least violation from the target storage at the end of the year. Adam et al. (2007) slightly changed this algorithm by considering new thresholds for allowable release and storage and used maximization of hydropower revenue as the objective function for reservoir operation.

There are two main issues with the proposed scheme. First, feasible reservoir releases are determined based on forecasted (or expected - Haddeland, 2014; personal communication) flow at dam location; and uncertainties in flow estimates can largely affect the search for optimal releases. Second, a high-dimensional search (e.g., 12 releases in the case of a monthly release simulation) must be performed for each operational year, which is computationally demanding. These issues were noted by van Beek et al. (2011). They modified the Haddeland et al. (2006a) algorithm to decrease the complexity and uncertainty associated with the algorithm. First, they defined the expected inflow for each month prospectively as a function of the flow in the same month of the previous years; therefore, they omitted using prognostic flow forecasts. In order to reduce the dimensionality of search, they considered reservoir release as a harmonic function; therefore, only release at beginnings of the release and the discharge periods needed to be determined. As the actual inflow values become available, the release can be consequently updated so that the final storage at the end of release period can meet the predefined target storage. With respect to determining the reservoir inflow based on naturalized or regulated flows, van Beek et al. (2011) noted that either setups can be used, depending on how the observed discharge is simulated at the large scale. This is due to large uncertainties in simulating the regulated runoff.

\section{Current large-scale modeling applications}

Water supply and allocation schemes reviewed in Sects. 2 and 3 have been used in a wide range of offline applications for estimation of human impacts on the terrestrial water cycle. Despite disagreements between different simulation results, the current literature agrees that the effects of water allocation are more pronounced at finer spatial and temporal scales. Earlier, Haddeland et al. (2007) studied the impacts of reservoir operation coupled with irrigation on continental runoff and argued that water allocation has resulted in 2.5 and $6 \%$ increase in annual runoff volume in North America and Asia, respectively. This is almost canceled out by increased evaporation due to irrigation. Nonetheless, as the analysis moves from global and continental to regional and large catchment scales, the effects of water allocation become more profound. For instance, while the mean annual runoff decreased in the western US by around $9 \%$ during a historical control period, the rate of decrement is around $37 \%$ in the Colorado River during the same period (Haddeland et al., 2006b). The results of the most recent global multi-model intercomparison showed that direct impacts of the water resource management in some regions, e.g., parts of Asia and in the western US, are similar or even more than the climate change effects (see Haddeland et al., 2014). Similarly, the effects of water allocation are more significant at finer timescales. For instance, Adam et al. (2007) noted that reservoirs have a minor effect on annual flows in Eurasian watersheds but have significant seasonal effects by changing the flow timing and seasonal amplitudes (see also Döll et al., 2009; van Beek et al., 2011; Biemans et al., 2011).

These simulations, however, are highly uncertain (see, e.g., Haddeland et al., 2011, 2014) due to major limitations in algorithms reviewed above, host large-scale models and data support. The efficiency of available water allocation algorithms can be diagnosed by comparing the streamflow obtained from simulations with observations. Currently, macro-scale water allocation schemes cannot fully describe the dynamics of regulated streamflows and there can be major disagreements between the regulated discharges obtained from different reservoir algorithms (Voisin et al., 2013a). It has been shown that calibration can improve the quality of reservoir operation algorithms (e.g., Wu and Chen, 2012); however, calibration is also associated with uncertainty and can potentially hinder model applications for future projections due to possible temporal and spatial variations in optimal parameters. Hanasaki et al. (2006) as well as Döll et al. (2009) showed that simulation-based algorithms can generally provide improved discharge simulations compared to lake routing algorithms. However, it should be noted that simulations still remain substantially biased in highly regulated catchments (e.g., San Francisco River, US; Syr Darya, central Asia) and in cold regions (e.g., Saskatchewan and Churchill rivers in Canada), particularly during high flows (e.g., Hanasaki et al., 2008a; Biemans et al., 2011; Pokhrel et al., 2012a). The simulation algorithm of Wu and Chen (2012) was found to be more accurate in simulating both storage and release compared to simple multi-linear regression and the target-release scheme embedded in SWAT (Arnold et al., 1998); however, it was tested only at the local scale and it is not clear how the algorithm can perform in other regions with different climate, level of regulation and allo- 
cation objectives. Very similar conclusions were obtained for optimization-based algorithms. Discharge simulations are generally improved compared to the no reservoir condition (e.g., Haddeland et al., 2006a); however, there are still significant deficiencies in simulating highly regulated flows, particularly in mountainous and cold regions such as Colorado River in the US as well as Yukon and Mackenzie rivers in Canada (e.g., Haddeland et al., 2006b; Adam et al., 2007). This relates in particular to prognostic reservoir inflows, which remain highly uncertain in these environments; this uncertainty contributes to the uncertainty in assigning optimal reservoir releases, often in dynamic and complex manners (Nazemi and Wheater, 2014b; Müller Schmied et al., 2014).

From a broader perspective, the current performance of reservoir operation and water allocation algorithms must be seen in the context of the hydrological performance of the host large-scale models, including how well the water demand has been represented (see Nazemi and Wheater, 2015). Currently, there are large biases in modeling hydrological processes across various scales, and runoff estimates remain widely divergent (e.g., Wisser et al., 2010; Haddeland et al., 2011; Gudmundsson et al., 2012; Hejazi et al., 2014). In particular, it has been shown that current simulations systematically underestimate streamflow in the arctic and subarctic regions and overestimate the observations in dry catchments; and reservoir operation algorithms mainly improve the timing of the flow, but not the volume (e.g., van Beek et al., 2011). While there are many potential reasons for this, one key source of this limitation is the quality of gridded precipitation products (Biemans et al., 2009, 2011). Rost et al. (2008) used different precipitation products to simulate the regulated river discharge and found substantial variations in simulated discharge due to the choice of precipitation data. Moreover, they showed that sometimes the total precipitation estimate could be less than the total observed discharge after abstraction and regulation. Upcoming satellite missions can address some of the issues regarding historical forcing (see the discussion of Sect. 5.3); however, uncertainty in future precipitation (and other climate variables) should be dealt systematically using multiple climate forcing options based on various combinations of concentration pathways, climate models and downscaling procedures.

Turning from surface water to groundwater issues, almost all available global studies agree on a significant increasing trend in groundwater withdrawal from the late 20th century onward. As an example, Wada et al. (2014) argued that, from 1990 to 2010, the rate of global groundwater withdrawal increased by around $3 \%$ a year. These results are in relatively good agreement with major observed depletions in some regional aquifers (see Gleeson et al., 2012). However, various quantified assessments and further conclusions such as regarding groundwater-induced sea-level rise remain highly uncertain and show major disagreements due to crude representation of groundwater availability, recharge and with- drawal, as discussed in Sects. 2.3 and 3.2 (see, e.g., Wada et al., 2010; Pokhrel et al., 2012b; Döll et al., 2014). This highlights an urgent necessity for improving the representation of human-groundwater interactions at larger scales.

\section{Towards an improved representation of water resource management in large-scale models}

\subsection{Ideal representation and remaining gaps}

Throughout our survey, we highlighted the importance of including water supply and allocation in conjunction with water demand (see Nazemi and Wheater, 2015) in models that are relevant to Earth system modeling and/or required for understanding large-scale hydrological responses, with both online and offline implications. From an integrated water resource management and land-surface modeling perspective, water demands can be considered as functions of climate, vegetation and soil moisture as well as socio-economic and policy variables (see Nazemi and Wheater, 2015). As shown in this paper, water supply is driven by water demands but controlled by natural surface-water and groundwater availability, which determine the maximum possible water allocation. Therefore, water demand and water supply should be systematically linked through a feedback loop, represented by water allocation. This integrated water resource system should be then linked to natural land-surface processes at the grid scale. This is rather intuitive: when considered in a typical grid, water allocation perturbs hydrological and landsurface variables within the grid. In parallel, the combined effects of land-surface and hydrological processes govern the variations in surface-water and groundwater availability, which consequently determine water demand (and accordingly water allocation) in the next simulation step. Figure 1 shows a simplified schematic for this integrated modeling framework, in which grid-based calculations of natural and anthropogenic land-surface are further coupled with climate through grid-based land-atmospheric feedbacks.

Major gaps remain in representing water resource management in LSMs in the way defined above. First, as also discussed in Nazemi and Wheater (2015), the key consideration in Earth system modeling is the conservation of mass, energy and water; however, this is widely violated in current models that include elements of water resource management (see Polcher, 2014). For instance, considering groundwater or NNBW as unlimited water sources necessitates bringing water to the system from outside the modeling domain, breaking the assumption that the Earth system is a closed system. This has particular importance when understanding the effects of human-water interactions on the climate and sea-level rise is sought.

Second, water resource management often takes place at the sub-grid resolution of current LSMs used for simulations over large regional and global scales (i.e., $50 \mathrm{~km}$ and more). 


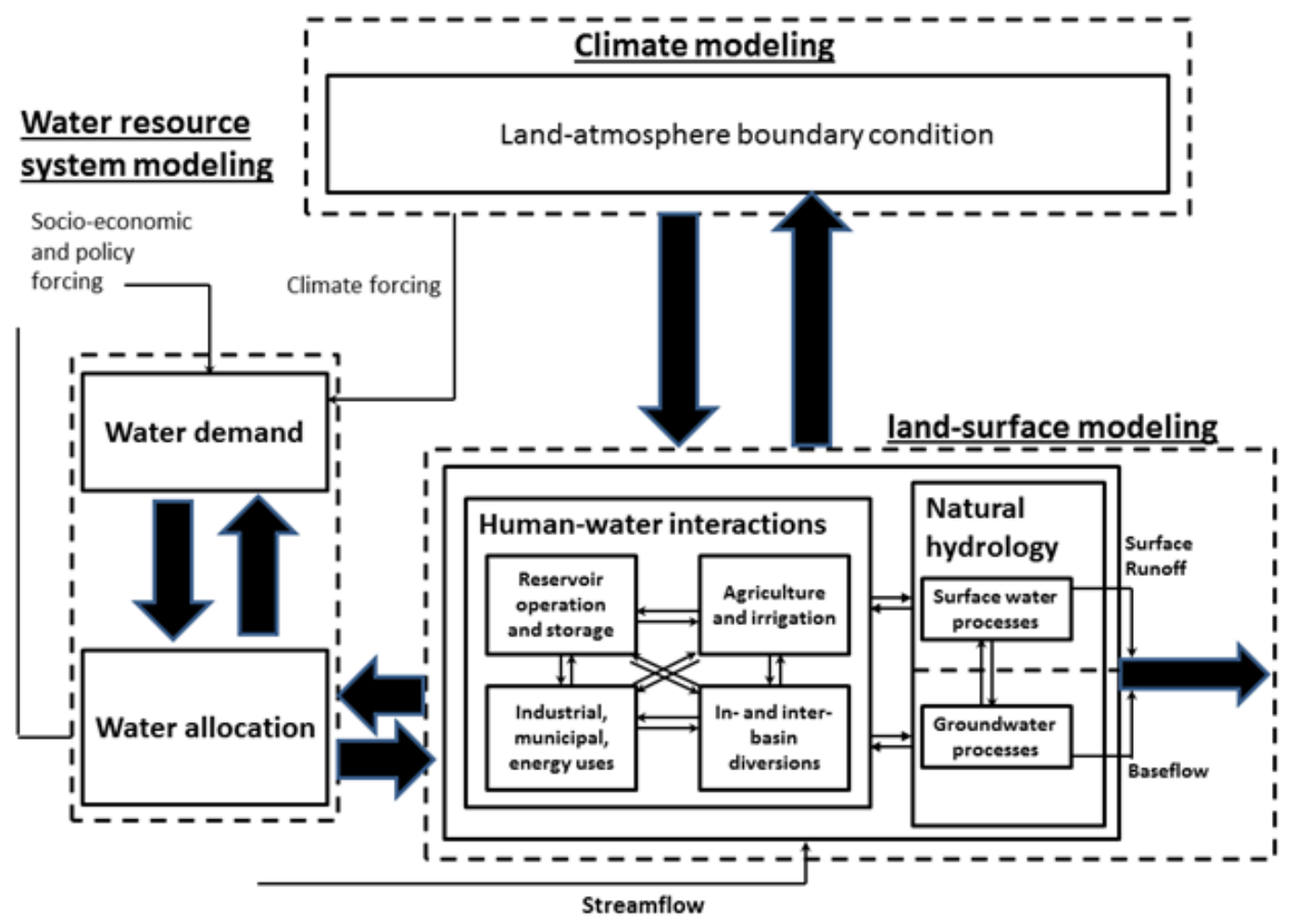

Figure 1. A fully coupled framework for inclusion of water resources management in a typical LSM grid.

Including the elements of water resource management therefore requires moving towards a "hyperresolution" scale (a few kilometers or less) for explicit representation (see Wood et al., 2011) and/or adding new sub-grid parameterizations related to human-water interactions, as illustrated in Fig. 1. However, as the resolutions become finer or more sub-grid parameterizations are added, modeling complexity, computational burdens and data requirements increase significantly, particularly in online simulation in which finer modeling resolution and better discretization of soil and vegetation is generally required to capture land-atmospheric feedbacks and possible climate responses (see Sorooshian et al., 2011a).

Third, we have noted that all currently available efforts in including water supply and allocation in large-scale models are offline and have been made mainly in the context of GHMs. GHMs provide an efficient platform for algorithm development and testing given the relative lack of computational constraints. However, self-evidently understanding online effects of large reservoir storage and large-scale groundwater pumping needs online simulations using coupled LSMs. At this stage of model development, however, many algorithms originally designed for offline applications might not be suitable for online implementations. An important example is reservoir operation, as both optimization- and simulation-based algorithms have some levels of prognosis that hinder their application in coupled simulations.
Fourth, online applications are associated with complexity in representing various feedbacks and time-scaling mismatch among different LSM component and water resource management (see Wang et al., 2004). In addition, current performance of online simulations is limited due to significant biases across different components and propagation of these biases throughout the fully coupled system.

Fifth, we have highlighted major limitations even in offline representation of water resource management at larger scales due to various sources of uncertainty. These uncertainties are due to (1) data support, particularly with respect to precipitation, actual water use and land-surface characteristics; (2) water demand, supply and allocation algorithms, particularly with respect to irrigation demand estimation, reservoir operation and groundwater withdrawals; as well as (3) host large-scale models, particularly with respect to those calculations that determine surface-water and groundwater availability. It should be noted that here we only focus on epistemic sources of uncertainty, which needs to be addressed, quantified, communicated and possibly reduced (see Beven and Alcock, 2012). Table 3 summarizes various aspects of uncertainty related to data support, algorithmic procedures and host models, identified for estimation of water demand (see Nazemi and Wheater, 2015) as well as water supply and allocation (see Sects. 2 to 4 ) in offline mode. It is often quite difficult to identify the exact source of uncertainty due to complex interconnections between various elements; 


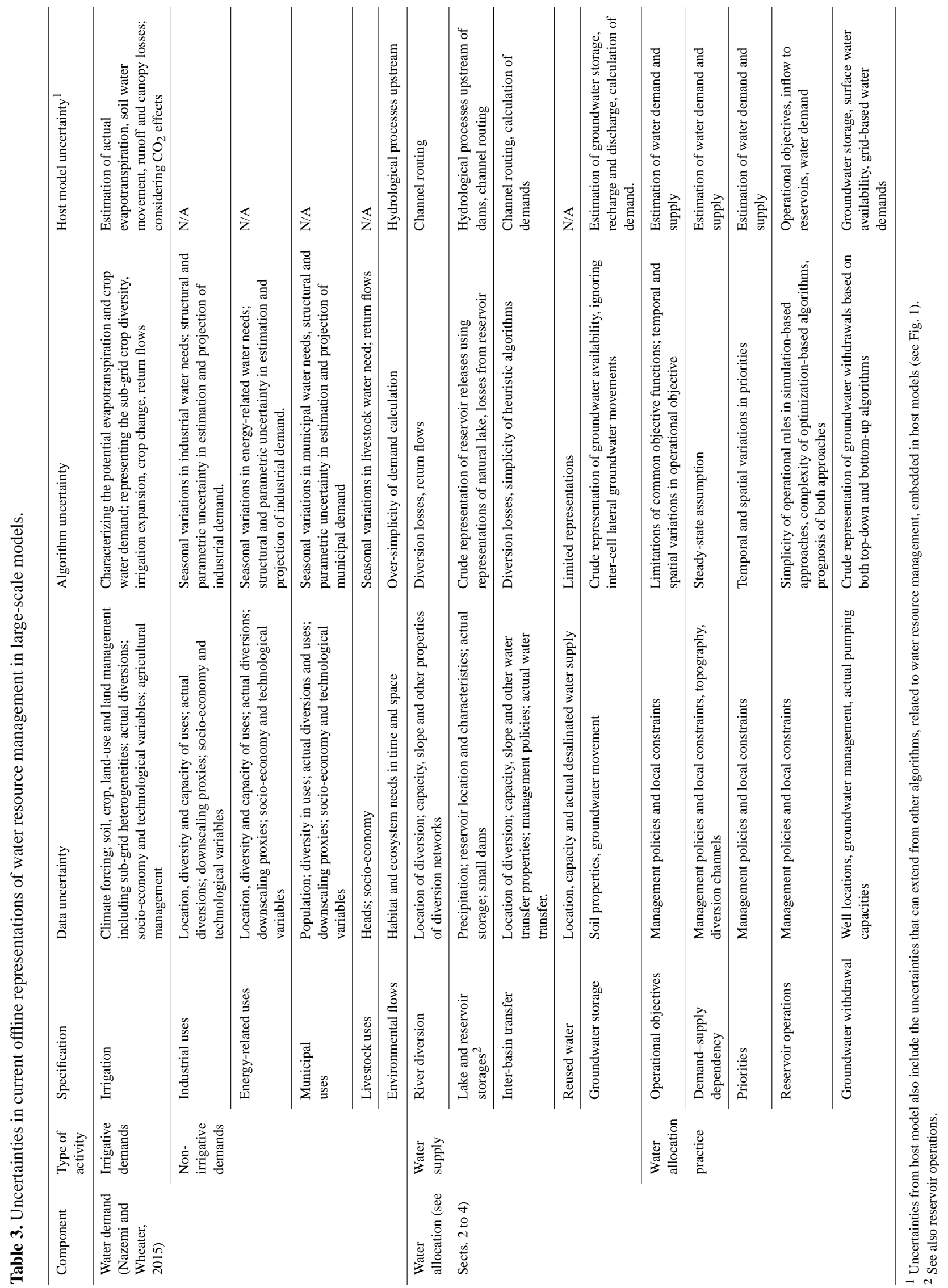


currently, a formal framework to test and validate the water resource management components in the face of various sources of uncertainty is not available (see also Beven and Cloke, 2012). In following sections, we briefly focus on these gaps and highlight the opportunities to address them and move towards the integrated representation proposed in Fig. 1.

\subsection{Outstanding challenges - closing the water balance and online simulations}

At this stage of research, issues around closing the water balance and online simulations are the most fundamental challenges in representing water resource management in Earth system models. Closing the water balance requires considering all sources of human water supply and withdrawals in the system and integrating them into the host large-scale models. One major gap in representing the water sources is groundwater, which is ignored or crudely represented in most current models. In parallel, as noted above, performing online simulations requires moving towards finer spatial and temporal scales and handling various sources of bias within the integrated system. Although providing an extensive discussion on issues around integrating groundwater models with LSMs as well as online Earth system modeling remains beyond the scope of this paper, here we attempt to briefly point to the main challenges and highlight a few opportunities for future developments.

Technically, the issues around coupling LSMs with groundwater and/or climate models are rather similar. In principle, (1) both require couplers to build an integrated model from independent models; (2) both require refining temporal and spatial resolutions; (3) both substantially increase the complexity of calculations; (4) both need research in terms of improving and adding new algorithms for process representations; and finally (5) both require handling various sources of uncertainty. Research on coupling individual models in an integrated Earth system modeling framework is ongoing, and currently there are various coupling strategies available (e.g., Dunlap et al., 2014). One challenge in coupling the elements of water resource management with climate is the mismatch between temporal scales of water resource management and natural cycles in the Earth system (Wang et al., 2004; Michetti and Zampieri, 2014). For instance, capturing the online effects of evaporation from reservoirs requires running the climate model with fine temporal resolution; although the reservoir evaporation is mainly a function of reservoir temperature and area, which vary slowly. Research, therefore, should be done to compare and optimize existing coupling strategies to handle such inconsistencies in time scaling.

One major need for representing groundwater and for online simulations is the necessity for moving towards finer spatial resolutions. This can result in various challenges. First, even if the spatial resolution increases, several sources of heterogeneity would still be ignored, as current LSMs do not consider them. For instance, LSMs usually define plant species based on plant functional types (PFTs), within which all parameters are identical. However, current LSMs recognize only limited PFTs and hence they typically ignore much of the biodiversity (Sato et al., 2014). Improvement in LSMs in terms of adding more detail into land-surface parameterization can provide opportunities to represent such sources of heterogeneity. Second, going toward finer modeling resolutions requires improved data support at finer scales. Although fine-resolution data are becoming more and more available (e.g., for soil properties - see Sato et al., 2014), such data sets are normally obtained from multiple independent sources, which differ in terms of their quality (see S. Liu et al., 2013). More efforts towards producing standardized and accurate data sources can support future fine-grid Earth system modeling. Finally, moving towards finer scales requires a new set of process representations and parameterizations (Hurrell et al., 2013). There are new developments along scale-aware parameterizations (e.g., Hurrell et al., 2009) that can help refine parameterizations for finer spatial scales.

One important issue with online simulations and groundwater modeling is the computational complexities compared to offline surface water simulations (e.g., Hill et al., 2004; Kollet et al., 2010; Wood et al., 2011). Wehner et al. (2008) suggested opportunities to address computational burdens, including hardware design (i.e., building enhanced computer processors for a specific application) and use of distributed and grid systems. A wide range of applications exists for grid and cloud computing systems (see Schwiegelshohn et al., 2010; Lecca et al., 2011; Fernández-Quiruelas et al., 2011). Improved computational power can also provide a basis to explore various model resolutions to identify critical scales for process representations (see Gentine et al., 2012) and to support computationally expensive offline calculations, such as groundwater processes, dynamic crop growth, river routing and model calibration (e.g., von Bloh et al., 2010; Rouholahnejad et al., 2012; Wu et al., 2013).

Understanding and handling various sources of uncertainty requires activities towards evaluating model performance against observations, which includes new diagnostics for systematic assessments of the modeling system. One key challenge is the fact that LSMs are run over large grids, whereas validation data for land-surface variables and groundwater can be only obtained at local scales. There are several attempts to overcome this issue. For instance, FLUXNET (http://www.daac.ornl.gov/FLUXNET/ fluxnet.shtml) coordinates regional and global analyses of observations from micrometeorological tower sites to fill validation gap for online LSMs. As Sato et al. (2014) indicated, such observation networks can facilitate diagnosing the LSM efficiency and sources of errors over large geographical scales. Moreover, a large number of combinations of model configurations should be tested to ensure reliability and performance of individual components and characterize 
the bias propagation from one component to others (Hurrell et al., 2013). For that purpose, it should be noted that increased modeling complexity does not necessarily result in an improved precision (see Sato et al., 2014; Smith et al., 2014); therefore, a systematic approach is required to test, intercompare and falsify modeling options in the light of validation data available. This will be discussed in more detail in Sect. 5.6.

\subsection{Data support}

As noted through our survey, major data limitations exist in representing various aspects of water resource management, which are related to forcing, parameterization, calibration and validation of water demand, supply and allocation algorithms (see also Table 3). At this stage of research, major gaps are noted in spatial and temporal quality and coverage of the data related to climate, hydrology, socio-economy, policy and water resource management that are required to drive or to support large-scale models (see Wood et al., 2011; Gleick et al., 2013; Oki et al., 2013).

One important opportunity to improve data support is the use of remote sensing technology, which can provide a synoptic view of the state of land-surface and atmospheric variables (see Sorooshian et al., 2011b; Asrar et al., 2013) and a reliable data support for dynamic forcing, parameter estimation as well as evaluation of large-scale models (see van Dijk and Renzullo, 2011; Trenberth and Asrar, 2012). For instance, Landsat missions (http://landsat.gsfc.nasa.gov; see Williams et al., 2006) have captured long-term variations in global land cover with a temporal resolution of 16 days and spatial resolution of up to $30 \mathrm{~m}$, which can help to parameterize anthropogenic activities such as crop growth and reservoir area. More recently, passive MODerate Resolution Imaging Spectroradiometer (MODIS; http://modis.gsfc. nasa.gov; see Savtchenko et al., 2004) has provided a wide range of land-surface information and has already been applied for various large-scale modeling studies, including validation of online models (Sorooshian et al., 2011a), highresolution parameterization (Ke et al., 2012) and monitoring storage in large reservoirs (Gao et al., 2012). Assimilation of MODIS land measurements with meteorological data and the Penman-Monteith equation has also provided 8-day, monthly and annual evapotranspiration estimates at $1 \mathrm{~km}$ resolution globally ( $\mathrm{Mu}$ et al., 2007, 2011). This can provide a basis to evaluate simulated evapotranspiration over land surface (see, e.g., Yilmaz et al., 2014). Another important product is the Gravity Recovery and Climate Experiment (GRACE; http://www.csr.utexas.edu/grace/; see Tapley et al., 2004), measuring changes in the total terrestrial water storage at rather coarser resolutions. GRACE data have already been used in studies related to regional groundwater depletion (e.g., Rodell et al., 2007, 2009), model calibration (e.g., Sun et al., 2012) and validation of large-scale simulations (e.g., Pokhrel et al., 2012a, b; Döll et al., 2014).
Upcoming satellite missions can further support representation of water resources management. For instance, precipitation is a key limitation in hydrological modeling in general, but is also important for irrigation demand and scheduling. The upcoming Global Precipitation Measurement mission (GPM; http://gpm.nasa.gov) will collect data at $10 \mathrm{~km}$ resolution, every $3 \mathrm{~h}$, globally. The upcoming Soil Moisture Active Passive mission (SMAP; see Entekhabi et al., 2010) will provide improved global soil moisture measurements every $24 \mathrm{~h}$ without sensitivity to cloud cover. This can be considered as an important data support for irrigation demand algorithms. Another upcoming remote sensing mission is the Surface Water and Ocean Topography mission (SWOT; see Fu et al., 2009; Biancamaria et al., 2010; Durand et al., 2010), which will provide fine-scale measurements of various surface water stores, including reservoirs as well as natural and man-made channels. Such information at the global scale has the potential to revolutionize representation, calibration and validation of algorithms related to estimation of inflow to reservoirs, reservoir releases and inter-basin water transfers.

There are also important improvements in sharing groundbased data and simulation results, including some inspiring grass-root data collection efforts. For example, the International Groundwater Resources Assessment Centre (IGRAC; http://www.un-igrac.org) assigns an associate expert to each 1-degree grid cell to submit monthly groundwater levels. Such data can be a critical source for testing groundwater withdrawal algorithms. Similar grass-root efforts could be made to record other water resource management data, particularly with respect to actual (rather than licensed) water uses, local management policies and water technologies. We also note that sharing of gridded climate forcing and simulation results is important and provides a basis for consistent model intercomparison efforts. One example is the recently finished EU-WATCH program (http://www. eu-watch.org/), which provides forcing and simulation results of WATCH's Model Intercomparison Project (WaterMIP; http://www.eu-watch.org/watermip).

\subsection{Water resource management algorithms}

Computational algorithms for representing the elements of water resource management have various sources of uncertainty (see Table 3), and improving the related representations and reducing the modeling uncertainty can be considered as an important avenue for future developments. Some important opportunities include enhancing the simulationbased reservoir operation algorithms for online applications and various applications of calibration, data assimilation and system identification techniques.

- One crucial limitation of current reservoir operation algorithms, as noted above, is in online applications. Simulation-based schemes provide a basis to move forward; however, modifications are required to relax prognostic inputs and to represent the thermal and evap- 
orative functions of reservoirs for online applications. Modeling schemes have already been developed for representing energy balance of natural lakes at sub-grid scale (e.g., MacKay, 2011; MacKay and Seglenieks, 2013) and can be merged with improved simulationbased reservoir operation algorithms to simultaneously characterize reservoir release, storage and evaporation as well as land-atmospheric feedbacks. However, an important question remains in how to address substantial biases in estimation of reservoir release due to the uncertainty in estimation of reservoir inflows, particularly in online simulations. This issue can be partially handled using data assimilation frameworks; but substantial uncertainty remains in future simulation, where assimilation is not possible. Therefore, efforts should be made to represent reservoirs in a robust manner that can handle the inflow biases.

- Calibration using observed, simulated or assimilated system behavior can be used to implicitly represent management and sub-grid heterogeneity. One example would be to address diversity in irrigation demand by finding "representative parameters" that match the assimilated evaporation over a typical irrigated grid. Calibration with ability to identify time-varying parameters could also be used to improve the performance of reservoir operation algorithms and provide a basis to account for variations in water allocation practice in time and potentially in space by considering functioning of multiple reservoirs.

- Another opportunity is to improve functional mappings of system response and demand through system identification techniques. These techniques can range from statistical regression models to more sophisticated machine-learning techniques such as artificial neural networks (e.g., Nazemi et al., 2006a) and genetic symbolic regression (e.g., Hassanzadeh et al., 2014). One example would be building functional relationships for estimation of irrigative or non-irrigative water demands and/or uses. Another would be to represent reservoir operations through transfer functions and enhanced rulebased models as well as building different decision support systems for handling operations taking place at different timescales (i.e., hydropower with a 5 min market, floods with sub-hourly to hourly time step, and monthly seasonal water supply). This can provide an interesting prospect to extract operational rules from observed data and to incorporate soft variables such as social values and expert insights into modeling water resource management (e.g., Nazemi et al., 2002). This can provide various opportunities, for instance for describing the operation of multiple reservoirs at the basin scale, which is widely ignored in the current large-scale reservoir operation schemes.

\subsection{Host models}

Limitations in host models can introduce a wide range of uncertainties (see Table 3). This is due to the fact that water resource management algorithms are fully embedded within the host models and interact with calculations related to landsurface processes at the grid scale (see Fig. 1). For instance, estimation of antecedent soil moisture affects estimation of irrigation demand. Similarly, estimates of inflows to reservoirs govern the calculations related to reservoir releases and storage. Currently, there are major limitations in representing soil moisture, snow cover, permafrost, evapotranspiration, deep percolation and runoff in large-scale models and they cannot be represented without large uncertainty (Lawrence et al., 2012; Trenberth and Asrar, 2012; Oki et al., 2013). Moreover, host models often contain missing processes. For instance, current host models often ignore the effects of increased $\mathrm{CO}_{2}$ concentration on irrigation demand. This may result in large uncertainties under climate change effects (see Wada et al., 2013).

While an extensive review of these issues goes beyond the scope of this paper, we note that substantial efforts continue to be made to include missing processes and to improve current parameterizations of natural and anthropogenic processes in large-scale models, particularly in the context of LSMs. For instance, the Community Land Model (CLM; Oleson et al., 2004; 2008; Lawrence et al., 2011) has been recently improved by new algorithms for representing permafrost (Swenson et al., 2012), agriculture (Drewniak et al., 2013) and irrigation (Levis and Sacks, 2011; Levis et al., 2012). Another important development is the vectorbased river routing algorithms (e.g., Li et al., 2013; Tesfa et al., 2014) that can improve the representation of natural and anthropogenic channel processes such as reservoir stores, streamflow diversions and inter-basin water transfers (see Lehner and Grill, 2013). Another key opportunity is the application of data assimilation and/or calibration techniques to reduce parametric uncertainty and to improve prediction capability. Some systematic frameworks for calibration and parameterization of land-surface processes are suggested (Rosolem et al., 2012, 2013). We expect improvements in process representations and parameterizations related to LSMs will increase in near future due to the need that has been already recognized (e.g., Wood et al., 2011; Lawrence et al., 2012; Trenberth and Asrar, 2012; Gleick et al., 2013; Oki et al., 2013; Dadson et al., 2013).

\subsection{A framework to move forward}

Several improvements need to be made in order to appropriately represent the elements of water resource management in Earth system models. We noted that moving towards including the elements of water resource management in a way described in Fig. 1 requires continuous developments in water resource management algorithms, host LSMs, on- 
Table 4. Required developments to include the elements of water resource management in Earth system models (see also Table 3).

\begin{tabular}{|c|c|c|c|c|}
\hline $\begin{array}{l}\text { Water } \\
\text { resource } \\
\text { management } \\
\text { component }\end{array}$ & $\begin{array}{l}\text { Required algorithmic } \\
\text { improvements }\end{array}$ & $\begin{array}{l}\text { Targeted spatial } \\
\text { scale }\end{array}$ & $\begin{array}{l}\text { Targeted } \\
\text { temporal scale }\end{array}$ & $\begin{array}{l}\text { Data support for } \\
\text { parameterization } \\
\text { and validation }\end{array}$ \\
\hline $\begin{array}{l}\text { Irrigation } \\
\text { demands }\end{array}$ & $\begin{array}{l}\text { Improving the calculation of } \\
\text { crop-specific water demand } \\
\text { considering the effect of } \\
\mathrm{CO}_{2} \text {, considering soil-water } \\
\text { movement and other losses }\end{array}$ & $\begin{array}{l}\text { Hyperresolution } \\
\text { and sub-grid } \\
\text { scale }\end{array}$ & $\begin{array}{l}\text { Sub-daily/sub- } \\
\text { hourly (for online } \\
\text { simulations) }\end{array}$ & $\begin{array}{l}\text { Crop and soil } \\
\text { diversity, measured } \\
\text { or assimilated } \\
\text { evaporation over } \\
\text { irrigated lands }\end{array}$ \\
\hline $\begin{array}{l}\text { Non-irrigative } \\
\text { human demands }\end{array}$ & $\begin{array}{l}\text { Improving the mapping } \\
\text { relationship, representing } \\
\text { the diversity of non- } \\
\text { irrigative demands }\end{array}$ & $\begin{array}{l}\text { Large grids with } \\
\text { the ability to be } \\
\text { downscaled into } \\
\text { finer resolutions } \\
\text { using socio- } \\
\text { economic and } \\
\text { climate proxies }\end{array}$ & $\begin{array}{l}\text { Yearly and } \\
\text { monthly with the } \\
\text { ability to be } \\
\text { downscaled into } \\
\text { finer scales using } \\
\text { socio-economic } \\
\text { and climate proxies }\end{array}$ & $\begin{array}{l}\text { Water use data, } \\
\text { gridded climate and } \\
\text { regional socio- } \\
\text { economic data }\end{array}$ \\
\hline $\begin{array}{l}\text { Environmental } \\
\text { flow needs }\end{array}$ & $\begin{array}{l}\text { Improving the demand } \\
\text { approximation considering } \\
\text { the diversity in the aquatic } \\
\text { life }\end{array}$ & Catchment scale & Monthly and less & $\begin{array}{l}\text { Aquatic } \\
\text { biodiversity and } \\
\text { water use, climate } \\
\text { information, water } \\
\text { temperature, water } \\
\text { quality }\end{array}$ \\
\hline $\begin{array}{l}\text { Lakes and } \\
\text { reservoirs }\end{array}$ & $\begin{array}{l}\text { Improving the } \\
\text { representation of release and } \\
\text { storage, linking hydrologic } \\
\text { representation with energy- } \\
\text { balance components }\end{array}$ & $\begin{array}{l}\text { Grid and } \\
\text { sub-grid }\end{array}$ & Daily & $\begin{array}{l}\text { Reservoir storage } \\
\text { and water level, } \\
\text { release downstream } \\
\text { of reservoirs, } \\
\text { storage-area- } \\
\text { elevation } \\
\text { relationships, } \\
\text { operational } \\
\text { objectives }\end{array}$ \\
\hline $\begin{array}{l}\text { Water } \\
\text { diversions }\end{array}$ & $\begin{array}{l}\text { Representing in-grid and } \\
\text { inter-grid water diversions } \\
\text { including losses }\end{array}$ & $\begin{array}{l}\text { Grid and } \\
\text { inter-grid }\end{array}$ & Daily & $\begin{array}{l}\text { Water distribution } \\
\text { specifications, } \\
\text { location of } \\
\text { abstractions }\end{array}$ \\
\hline Groundwater & $\begin{array}{l}\text { Improving the } \\
\text { representation of } \\
\text { groundwater storage } \\
\text { and recharge }\end{array}$ & Grid & $\begin{array}{l}\text { Daily (shorter in } \\
\text { online simulations) }\end{array}$ & $\begin{array}{l}\text { Soil properties, well } \\
\text { locations, pumping } \\
\text { capacities }\end{array}$ \\
\hline $\begin{array}{l}\text { Water reuse } \\
\text { and desalination }\end{array}$ & $\begin{array}{l}\text { Improving the } \\
\text { representation of water } \\
\text { reuse and desalination and } \\
\text { the annual dynamics of } \\
\text { water supply from each } \\
\text { facility }\end{array}$ & Grid & $\begin{array}{l}\text { Yearly with the } \\
\text { ability to be } \\
\text { downscaled into } \\
\text { finer timescales } \\
\text { using climate and } \\
\text { socio-economic } \\
\text { proxies }\end{array}$ & $\begin{array}{l}\text { Location and } \\
\text { capacity of } \\
\text { facilities, gridded } \\
\text { climate, regional } \\
\text { socio-economic data }\end{array}$ \\
\hline
\end{tabular}

line land-atmospheric coupling and data support. We pointed to the main gaps and provided a brief overview on the opportunities for overcoming these limitations. As far as the algorithms related to representing water resource management are concerned, Table 4 summarizes improvements that need to be made before we can properly represent humanwater interaction in Earth system models, along with targeted temporal and spatial resolutions. Modeling resolutions can vary across various elements of water resource managements due to the difference in how different elements affect 
water and energy balance at the land surface. For instance, irrigation and crop growth directly affect both energy and water balance at the sub-grid scale, with substantial difference between crop function during a day. Therefore, irrigation should be represented at a fine temporal and spatial resolution to capture potential climate responses. Reservoirs also affect water and energy balance; however, as noted above reservoir area and surface temperature vary slowly and therefore there is no need to approach a finer timescale than the scale needed for representing the water balance and downstream releases.

As noted throughout our survey, a variety of modeling options for representing key elements of water resource management at larger scales is currently available and new details about natural and anthropogenic processes are continually being added to Earth system models. Nonetheless, major limitations exist in current data, algorithms and host models, which induce major biases within components and complicate uncertainty quantification and model tractability. At this juncture, a primary task for model development should be to test and compare different data and modeling alternatives in an integrated system. This requires considering model hierarchy and the links between different components and exploring individual and integrated model space with respect to accuracy, identifiability and capability for generalization. This, in turn, can direct where future attempts should be focused to reduce uncertainties further (see also Smith et al., 2014; Michetti and Zampieri, 2014). Guidelines are available for (1) considering multiple working hypotheses for supporting and representing relevant sub-processes and modeling component; (2) constructing different simulations based on various combinations of the considered options and (3) rejecting them if they fail to describe new data, violate their underlying assumptions and/or can be equally described by simpler models (M. P. Clark et al., 2011; see Popper, 1959). Modular systems, such as the recently released WRF-Hydro (Gochis et al., 2013), are particularly suitable for building such a framework as they provide a tool for constructing/falsifying different hypotheses for process representations, parameterizations and data support in a unified computational platform.

To address this and to move towards the integrated representation of water resource management in LSMs, suggested in Fig. 1, we propose a systematic framework for improving the incorporation of water resource management through building, testing and falsifying various modeling options. Figure 2 shows this framework based on the links between different modeling components. In brief, Fig. 2 divides the model development into six components, related to (a) modeling setup and data configuration, (b) climate modeling, (c) land-surface modeling, (d) water resource management representation, (e) calibration and parametric identification, as well as (f) testing and falsification. The framework starts with prior knowledge (a), coming from the modeling purpose, current modeling capabilities and limitations and the knowledge obtained from previous modeling attempts.
According to the prior knowledge and emerging advancements, a range of modeling scales can be selected and multiple working hypotheses can be configured to represent the data and modeling options in (b) to (e). Depending on the mode and period of simulation, climate data or more generally climate models (b) are required to force or to be coupled with land-surface processes. The land-surface component (c) includes relevant sub-modules related to natural processes, water supply and allocation and irrigative and non-irrigative withdrawals. The anthropogenic activities are controlled by the water resource management component (d), which requires inputs from land-surface and climate components to determine water availability and to estimate various demands with the aid of these and/or other proxies (priori knowledge). Rules for prioritizing, partitioning and allocating water demands are reflected in a management decision sub-module that further drives water allocation in the land-surface modeling component. Sub-modules within (c) and (d) often contain unknown parameters that need to be identified through prior knowledge or calibration. As a result, calibration and parameter identification algorithms (e) with capability for further uncertainty assessment are a key requirement. Populationbased optimization algorithms are particularly suitable for parameter identification as they provide a range of behavioral parameters, which can be analyzed through advanced visualization schemes and provide valuable insights into modeling uncertainty, identifiability and multiple performance measures (e.g., Nazemi et al., 2006b, 2008; Pryke et al., 2007). Moreover, population-based algorithms can provide methodological linkage to uncertainty assessment through various diagnostic tests. Guidelines are provided to test and falsify models through various evaluation criteria such as parametric identifiability (e.g., Beven, 2006b), Pareto optimality (Gupta et al., 1998), predictive uncertainty (Wagener et al., 2004) and limits of acceptability (Beven and Alcock, 2012).

Due to the current stage of model development, there is a need to approach the framework suggested in Fig. 2 with a sequential workflow, as certain improvements should be made first before we can improve others. Figure 3 divides the suggested framework into four sequential working packages. First, various options for data support, water resource management (WRM) algorithms and host models should be benchmarked, tested and intercompared individually to highlight their relative suitability in further offline simulation. This would naturally result in falsifying some of the working hypotheses. The selected options then should be mixed and matched in an offline mode. The offline simulation efficiency should be then explored and intercompared between various integrated settings to assess the biases propagated across the system and examine the robustness of the individual components in an integrated offline simulation. The non-falsified options in this stage can be further improved and configured for online simulation, which can be then coupled with climate models in a way described in Fig. 2. 


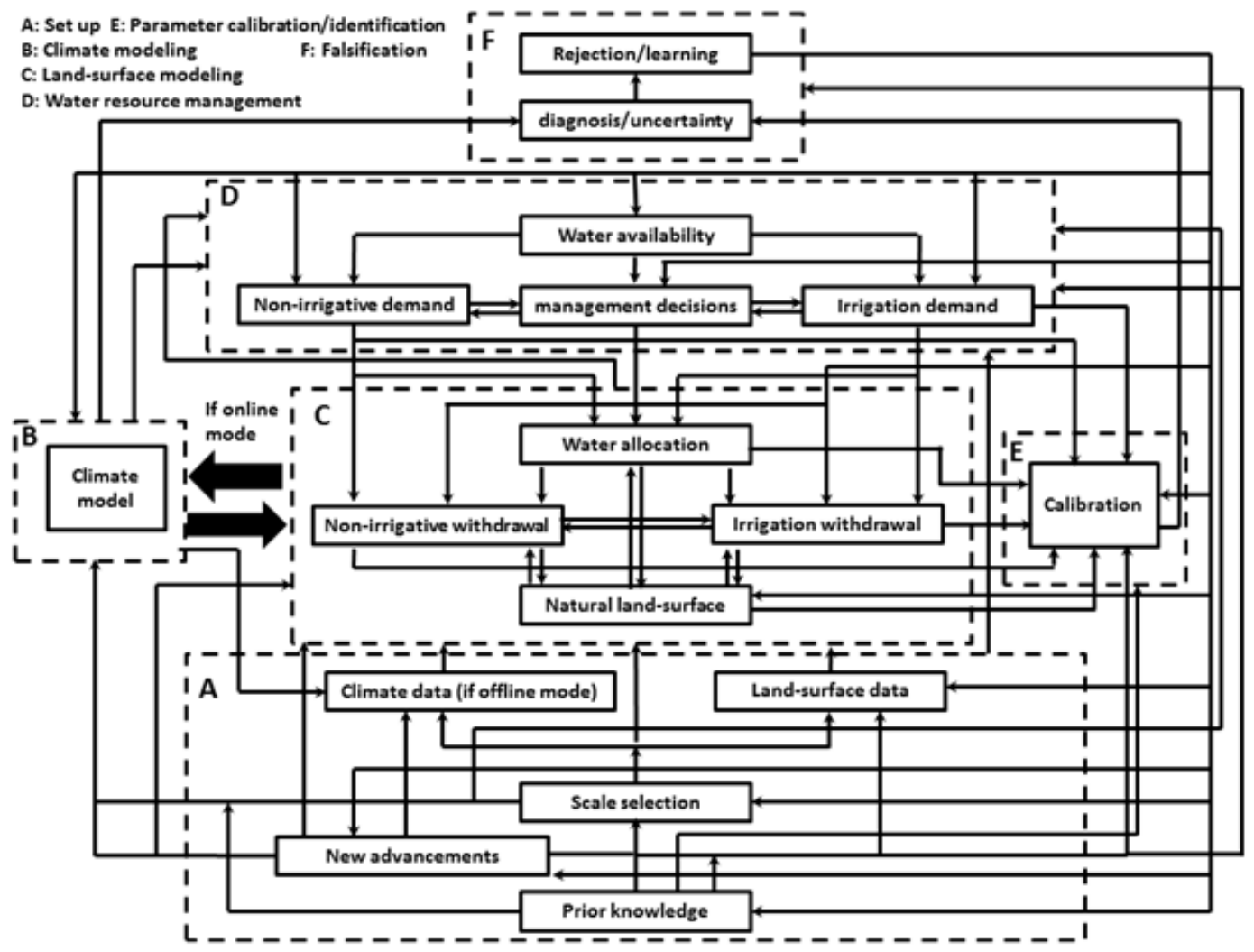

Figure 2. A modular framework for improving the inclusion of water resource management in LSMs through building, testing and falsifying multiple working hypotheses.

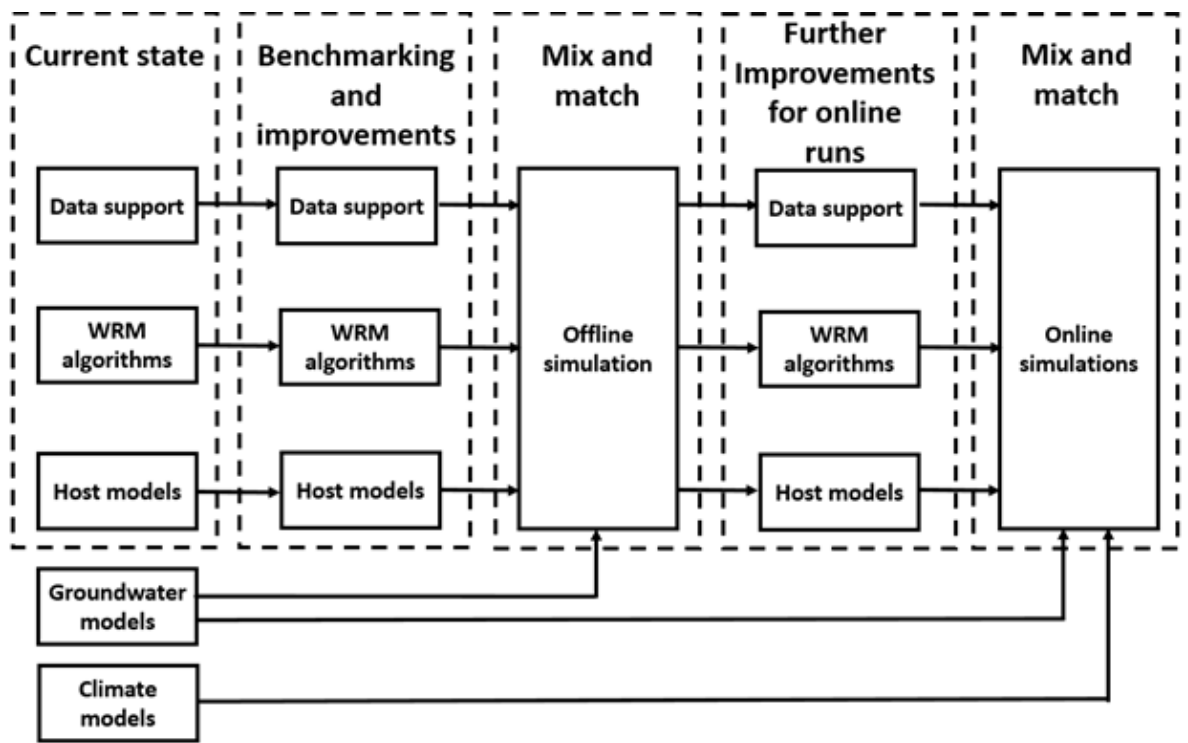

Figure 3. A sequential workflow for benchmarking, improving and including the elements of water resource management into offline and online Earth system simulations. 
A key requirement for implementing the suggested framework is the availability of suitable data, at an appropriate scale, for algorithm development and intercomparison. Although global studies are important to improve our knowledge of the Earth system and global water supply, our ability to conduct a comprehensive global study as proposed in Fig. 2 is currently limited due to methodological, computational and funding barriers. We argue that a network of regional case studies, however, could provide access to local data, and a sample of comparative examples to support algorithm intercomparison and further development. We note, for example, the success of model intercomparison projects such as MOPEX (Duan et al., 2006) for hydrological modeling, and suggest that the time is right to develop a similar initiative for the incorporation of anthropogenic effects in hydrological models. One possibility is to draw on the resources of the set of Regional Hydroclimate Projects (RHPs) supported by the Global Energy and Water Exchanges (GEWEX) initiative of the World Climate Research Program (WCRP). As an example, our home river basin in western Canada, the $340000 \mathrm{~km}^{2}$ transboundary Saskatchewan River basin (SaskRB), is a GEWEX RHP, embodies a complex largescale water resources system (Nazemi et al., 2013), and poses globally relevant science and management challenges (see Wheater and Gober, 2013). These require improved representation of water resource management at larger scales to diagnose the changes in the regional discharge, climate and water security as the result of current and future water resource management and climate change. Such RHPs could provide a basis for model development and intercomparison to support inclusion of water resource management in Earth system models for fully coupled global simulations. We have already started to explore various modeling options and the ways of improving individual algorithms (i.e., stage 1 of sequential model development protocol illustrated in Fig. 3) throughout the SaskRB. For instance, we have benchmarked several reservoir operation algorithms using observed inflows and assessed the possibility of improving simulation using calibration. We have realized that the efficiency of reservoir operation algorithms can be considerably improved if the assumption of fixed model parameterization is relaxed and the algorithm parameters are identified through calibration against observed reservoir level and discharge. We are about to finalize this study and will present our findings through a technical paper in near future.

\section{Summary and concluding remarks}

Human water supply and allocation have intensively perturbed the water cycle. We noted that the inclusion of these anthropogenic activities in Earth system models poses a new set of modeling challenges and progress has remained incomplete. Despite some major developments, we noted that current limitations significantly degrade the modeling capa- bility at larger scales, particularly with respect to future conditions, and neglect potentially significant sources of change to land-atmospheric system. We highlighted important deficiencies related to representing groundwater stores and withdrawals as well as online implications of large reservoirs. We also noted that current water allocation algorithms have considerable limitations in representing streamflow in regulated catchments. We argued that these limitations are attributed to uncertainties in data support, water allocation algorithms and host large-scale models.

We identified four opportunities for improvements. These are advancements in (1) high-performance computing and coupling techniques; (2) remote sensing, data collection and data sharing; (3) calibration algorithms, system identification techniques and assimilation products; and (4) ongoing improvements in host models including both process representation and parameter identification. As there are several options available for data support, water resource management algorithms and host models, we proposed a modular framework for testing various modeling and data options, which can be configured by multiple working hypotheses and implemented in a unified and fully integrated modeling framework. The selected working hypotheses can be tested and falsified on the basis of available information, intercomparison and/or various model diagnosis frameworks. Similar to other recent commentaries (e.g., M. P. Clark et al., 2011; see also Beven et al., 2012), we believe that such a systematic framework in essential for improving current modeling capability in both offline and online modes and can be pursued using regional case studies, before aiming for fully coupled global simulations. WCRP RHPs are one source of suitable examples to move this agenda forward.

It should be noted that filling current gaps in the inclusion of water resource management in Earth system models requires substantial efforts across a wide range of disciplines, from social and policy sciences to economics and water management, from natural sciences to engineering and mathematical modeling, and from remote sensing to hardware technology and computer science. Interdisciplinary research efforts, therefore, are important. Moreover, for various reasons including funding limitations, the community needs to fully recognize the role of collaboration and explore various opportunities to share data and resources for efficient model developments and for consistent intercomparisons.

Finally, it should be indicated that our survey considered water resource management from a water quantity perspective. Water quality concerns are increasingly associated with growing human water demand and can also impact water supply and allocation. Coupling water quality and quantity in Earth system models is however very much in its infancy, and much future effort will be required to fill this gap. We hope that our survey will trigger more attention towards the necessity for improving current Earth system modeling capability to respond to the needs and challenges of the "Anthropocene". 
Acknowledgements. The first author has attended NASA's Applied Remote Sensing Training free webinar series (http://water.gsfc.nasa.gov/) and would like to thank Amita Mehta, Evan Johnson and John Bolten for providing useful materials related to remote sensing technology. The authors gratefully acknowledge the constructive comments from the editor and two anonymous reviewers as well as Jan Polcher, Ingjerd Haddeland, Naota Hanasaki, Jason Evans and Bruce Davison, which have enabled us to make significant improvements to this paper. Financial support for this survey was provided by the Canada Excellence Research Chair in Water Security at the University of Saskatchewan..

Edited by: W. Buytaert

\section{References}

Adam, J. C. and Lettenmaier, D. P.: Application of new precipitation and reconstructed streamflow products to streamflow trend attribution in northern Eurasia, J. Climate, 21, 807-1828, 2008.

Adam, J. C., Haddeland, I., Su, F., and Lettenmaier, D. P.: Simulation of reservoir influences on annual and seasonal streamflow changes for the Lena, Yenisei and Ob'rivers, J. Geophys. Res.Atmos., 112, D24114, doi:10.1029/2007JD008525, 2007.

Alcamo, J., Döll, P., Henrichs, T., Kaspar, F., Lehner, B., Rösch, T., and Siebert, S.: Development and testing of the WaterGAP 2 global model of water use and availability, Hydrolog. Sci. J., 48, 317-337, 2003.

Alcamo, J., Flörke, M., and Märker, M.: Future long-term changes in global water resources driven by socio-economic and climatic changes, Hydrolog. Sci. J., 52, 247-275, 2007.

Arnell, N. W.: Climate change and global water resources: SRES emissions and socio-economic scenarios, Global Environ. Change, 14, 31-52, 2004.

Arnold, J. G., Srinivasan, R., Muttiah, R. S., and Williams, J. R.: Large area hydrologic modeling and assessment part i: model development, J. Ame. Water Resour. Assoc., 34, 73-89, doi:10.1111/j.1752-1688.1998.tb05961.x, 1998.

Asrar, G. R., Hurrell, J. W., and Busalacchi, A. J.: A need for "actionable" climate science and information: summary of WCRP Open Science Conference, B. Am. Meteorol. Soc., 94, ES8ES12, 2013.

Bellman, R.: On the theory of dynamic programming, P. Natl. Acad. Sci., 38, 716-719, 1952.

Bergström, S. and Singh, V. P.: The HBV model, in: Computer models of watershed hydrology, edited by: Singh, V. P., Water Resources Publications, Colorado, USA, 443-476, 1995.

Best, M. J., Pryor, M., Clark, D. B., Rooney, G. G., Essery, R .L. H., Ménard, C. B., Edwards, J. M., Hendry, M. A., Porson, A., Gedney, N., Mercado, L. M., Sitch, S., Blyth, E., Boucher, O., Cox, P. M., Grimmond, C. S. B., and Harding, R. J.: The Joint UK Land Environment Simulator (JULES), model description Part 1: Energy and water fluxes, Geosci. Model Dev., 4, 677-699, doi:10.5194/gmd-4-677-2011, 2011.

Beven, K.: Searching for the Holy Grail of scientific hydrology: $Q_{t}=(S, R, \Delta t) A$ as closure, Hydrol. Earth Syst. Sci., 10, 609618, doi:10.5194/hess-10-609-2006, 2006a.
Beven, K.: A manifesto for the equifinality thesis, J. Hydrol., 320, 18-36, 2006b.

Beven, K., Smith, P., Westerberg, I., and Freer, J.: Comment on "Pursuing the method of multiple working hypotheses for hydrological modeling" by P. Clark et al., Water Resour. Res., 48, W11801, doi:10.1029/2012WR012282, 2012.

Beven, K. J. and Alcock, R. E.: Modelling everything everywhere: a new approach to decision-making for water management under uncertainty, Freshwater Biol., 57, 124-132, 2012.

Beven, K. J. and Cloke, H. L.: Comment on "Hyperresolution global land surface modeling: Meeting a grand challenge for monitoring Earth's terrestrial water" by Eric F. Wood et al., Water Resour. Res., 48, W01801, doi:10.1029/2011WR010982, 2012.

Biancamaria, S., Andreadis, K. M., Durand, M., Clark, E. A., Rodriguez, E., Mognard, N. M., Alsdorf, D. E., Lettenmaier, D. P., and Oudin, Y.: Preliminary characterization of SWOT hydrology error budget and global capabilities, IEEE J. Sel. Top. Appl., 3, 6-19, 2010.

Biemans, H., Hutjes, R. W. A., Kabat, P., Strengers, B. J., Gerten, D., and Rost, S.: Effects of Precipitation Uncertainty on Discharge Calculations for Main River Basins, J. Hydrometeorol., 10, 1011-1025, 2009.

Biemans, H., Haddeland, I., Kabat, P., Ludwig, F., Hutjes, R. W. A., Heinke, J., von Bloh, W., and Gerten, D.: Impact of reservoirs on river discharge and irrigation water supply during the 20th century, Water Resour. Res., 47, W03509, doi:10.1029/2009WR008929, 2011.

Blanc, E., Strzepek, K., Schlosser, A., Jacoby, H. D., Gueneau, A., Fant, C., Rausch, S., and Reilly, J.: Analysis of U.S. water resources under climate change, MIT Joint Program on the Science and Policy of Global Change, Report No. 239, http://globalchange.mit.edu/files/document/ MITJPSPGC_Rpt239.pdf (last access: 6 May 2014), 2013.

Chen, J. and $\mathrm{Wu}, \mathrm{Y}$.: Exploring hydrological process features of the East River (Dongjiang) basin in south China using VIC and SWAT, in: Proceedings of the International Association of Hydrological Sciences and the International Water Resources Association Conference, Guangzhou, China, IAHS Press, Wallingford, UK, 116-123, 2008.

Chow, V. T., Maidment, D. R., and Mays, L. W.: Applied Hydrology, McGraw-Hill Series in Water Resources and Environmental Engineering, McGraw-Hill, New York, 572 pp., 1998.

Clark, D. B., Mercado, L. M., Sitch, S., Jones, C. D., Gedney, N., Best, M. J., Pryor, M., Rooney, G. G., Essery, R. L. H., Blyth, E., Boucher, O., Harding, R. J., Huntingford, C., and Cox, P. M.: The Joint UK Land Environment Simulator (JULES), model description - Part 2: Carbon fluxes and vegetation dynamics, Geosci. Model Dev., 4, 701-722, doi:10.5194/gmd-4-701-2011, 2011.

Clark, M. P., Kavetski, D., and Fenicia, F.: Pursuing the method of multiple working hypotheses for hydrological modeling, Water Resour. Res., 47, W09301, doi:10.1029/2010WR009827, 2011.

Dadson, S., Acreman, M., and Harding, R.: Water security, global change and land-atmosphere feedbacks, Philos. T. Roy. Soc. A, 371, 2002, doi:10.1098/rsta.2012.0412, 2013.

Dankers, R., Arnell, N. W., Clark, D. B., Falloon, P. D., Fekete, B. M., Gosling, S. N., Heinke, J., Kim, H., Masaki, Y., Satoh, Y., Stacke, T., Wada, Y., and Wisser, D.: First look at changes in flood hazard in the Inter-Sectoral Impact Model Intercompari- 
son Project ensemble, P. Natl. Acad. Sci. USA, 111, 3257-3261, doi:10.1073/pnas.1302078110, 2014.

Dantzig, G. B.: Linear Programming and Extensions, Princeton University Press, New Jersey, USA, 1965.

Dirmeyer, P. A., Dolman, A. J., and Sato, N.: The pilot phase of the global soil wetness project, B. Am. Meteorol. Soc., 80, 851-878, 1999.

Döll, P., Kaspar, F., and Lehner, B.: A global hydrological model for deriving water availability indicators: model tuning and validation, J. Hydrol., 270, 105-134, 2003.

Döll, P., Fiedler, K., and Zhang, J.: Global-scale analysis of river flow alterations due to water withdrawals and reservoirs, Hydrol. Earth Syst. Sci., 13, 2413-2432, doi:10.5194/hess-13-24132009, 2009.

Döll, P., Hoffmann-Dobrev, H., Portmann, F. T., Siebert, S., Eicker, A., Rodell, M., Strassberg, G., and Scanlon, B. R.: Impact of water withdrawals from groundwater and surface water on continental water storage variations, J. Geodyn., 59, 143-156, 2012.

Döll, P., Müller Schmied, H., Schuh, C., Portmann, F. T., and Eicker, A.: Global-scale assessment of groundwater depletion and related groundwater abstractions: Combining hydrological modeling with information from well observations and GRACE satellites, Water Resour. Res., 50, 5698-5720, doi:10.1002/2014WR015595, 2014

Drewniak, B., Song, J., Prell, J., Kotamarthi, V. R., and Jacob, R.: Modeling agriculture in the Community Land Model, Geosci. Model Dev., 6, 495-515, doi:10.5194/gmd-6-495-2013, 2013.

Duan, Q., Schaake, J., Andreassian, V., Franks, S., Goteti, G., Gupta, H. V., Gusev, Y. M., Habets, F., Hall, A., Hay, L., Hogue, T., Huang, M., Leavesley, G., Liang, X., Nasonova, O. N., Noilhan, J., Oudin, L., Sorooshian, S., Wagener, T., and Wood, E. F.: Model Parameter Estimation Experiment (MOPEX): an overview of science strategy and major results from the second and third workshops, J. Hydrol., 320, 3-17, 2006.

Dunlap, R., Vertenstein, M., Valcke, S., and Craig, T.: Second Workshop on Coupling Technologies for Earth System Models, B. Am. Meteorol. Soc., 95, ES34-ES38, 2014.

Durand, M., Rodriguez, E., Alsdorf, D. E., and Trigg, M.: Estimating river depth from remote sensing swath interferometry measurements of river height, slope, and width, IEEE J. Select. Top. Appl. Earth Obs. Rem. S., 3, 20-31, 2010.

Entekhabi, D., Njoku, E. G., O’Neill, P. E., Kellogg, K. H., Crow, W. T., Edelstein, W. N., Entin, J. K., Goodman, S. D., Jackson, T. J., Johnson, J., Kimball, J., Piepmeier, J. R., Koster, R. D., Martin, N., McDonald, K. C., Moghaddam, M., Moran, S., Reichle, R., Shi, J.-C., Spencer, M. W., Thurman, S. W., Leung, T., and Van Zyl, J.: The Soil Moisture Active Passive (SMAP) mission, Proc. IEEE, 98, 704-716, 2010.

Falkenmark, M.: Growing water scarcity in agriculture: future challenge to global water security, Philos. T. Roy. Soc. A, 371, 2002, doi:10.1098/rsta.2012.0410, 2013.

Fan, Y. and Miguez-Macho, G.: A simple hydrologic framework for simulating wetlands in climate and earth system models, Clim. Dyn., 37, 253-278, 2011.

Fekete, B. M., Vörösmarty, C. J., and Grabs, W.: Global, composite runoff fields based on observed river discharge and simulated water balances, http://www.bafg.de/GRDC/EN/02_srvcs/24rprtsrs/ report22.pdf?_blob=publicationFile (last access: 6 May 2014), 1999.
Fekete, B. M., Vöröosmarty, C. J., and Grabs, W.: High-resolution fields of global runoff combining observed river discharge and simulated water balances, Global Biogeochem. Cy., 16, 15-115-10, doi:10.1029/1999GB001254, 2002.

Ferguson, I. M. and Maxwell, R. M.: The role of groundwater in watershed response and land surface feedbacks under climate change, Water Resour. Res., 46, W00F02, doi:10.1029/1999GB001254, 2010.

Fernández-Quiruelas, V., Fernández, J., Cofiño, A. S., Fita, L., and Gutiérrez, J. M.: Benefits and requirements of grid computing for climate applications: An example with the community atmospheric model, Environ. Model. Softw., 26, 1057-1069, 2011.

Foster, S. and Loucks, D. P.: Non-renewable groundwater resources: A guidebook on Socially-sustainable Management for Water-policy Makers, UNESCO, http://unesdoc.unesco.org/ images/0014/001469/146997e.pdf (last access: 6 May 2014), 2006.

Fu, L. L., Alsdorf, D., Rodriguez, E., Morrow, R., Mognard, N., Lambin, J., Vaze, P., and Lafon, T.: The SWOT (Surface Water and Ocean Topography) mission: spaceborne radar interferometry for oceanographic and hydrological applications, in: Proceedings of OCEANOBS'09 Conference, available at: http: //bprc.osu.edu/water/publications/oceanobs09_swot.pdf (last access: 6 May 2014), 2009.

Gao, H., Birkett, C., and Lettenmaier, D. P.: Global monitoring of large reservoir storage from satellite remote sensing, Water Resour. Res., 48, W09504, doi:10.1029/2012WR012063, 2012.

Gentine, P., Troy, T. J., Lintner, B. R., and Findell, K. L.: Scaling in surface hydrology: progress and challenges, J. Contemp. Water Res. Educ., 147, 28-40, 2012.

Gerten, D., Schaphoff, S., Haberlandt, U., Lucht, W., and Sitch, S.: Terrestrial vegetation and water balance - hydrological evaluation of a dynamic global vegetation model, J. Hydrol., 286, 249270, 2004.

Gleeson, T., VanderSteen, J., Sophocleous, M. A., Taniguchi, M., Alley, W. M., Allen, D. M., and Zhou, Y.: Groundwater sustainability strategies, Nat. Geosci., 3, 378-379, 2010.

Gleeson, T., Wada, Y., Bierkens, M. F., and van Beek, L. P.: Water balance of global aquifers revealed by groundwater footprint, Nature, 488, 197-200, 2012.

Gleick, P. H.: The world's water 2000-2001: the biennial report on freshwater resources, Island Press, Washington, D.C., 2000.

Gleick, P. H., Cooley, H., Famiglietti, J. S., Lettenmaier, D. P., Oki, T., Vörösmarty, C. J., and Wood, E. F.: Improving Understanding of the Global Hydrologic Cycle, in: Climate Science for Serving Society, edited by: Asrar, G. R. and Hurrell, J. W., Springer Netherlands, 151-184, 2013.

Gochis, D. J., Yu, W., and Yates, D. N.: The WRF-Hydro model technical description and user's guide, version 1.0, NCAR Technical Document, http://www.ral.ucar.edu/projects/ wrfhydro/ (last access: 6 May 2014), 2013.

Goldberg, D. E.: Genetic algorithms in search, optimization, and machine learning, Addison-wesley, Reading, Menlo Park, 1989.

Grey, D., Garrick, D., Blackmore, D., Kelman, J., Muller, M., and Sadoff, C.: Water security in one blue planet: twenty-first century policy challenges for science, Philos. T. Roy. Soc. A, 371, 2002, doi:10.1098/rsta.2012.0406, 2013.

Gudmundsson, L., Tallaksen, L. M., Stahl, K., Clark, D. B., Dumont, E., Hagemann, S., Bertrand, N., Gerten, D., Heinke, J., 
Hanasaki, N., Voss, F., and Koirala, S.: Comparing large-scale hydrological model simulations to observed runoff percentiles in Europe, J. Hydrometeorol., 13, 604-620, 2012.

Gupta, H. V., Sorooshian, S., and Yapo, P. O.: Toward improved calibration of hydrologic models: Multiple and noncommensurable measures of information, Water Resour. Res., 34, 751-763, doi:10.1029/97WR03495, 1998.

Haddeland, I., Skaugen, T., and Lettenmaier, D. P.: Anthropogenic impacts on continental surface water fluxes, Geophys. Res. Lett., 33, L08406, doi:10.1029/2006GL026047, 2006a.

Haddeland, I., Lettenmaier, D. P., and Skaugen, T.: Effects of irrigation on the water and energy balances of the Colorado and Mekong river basins, J. Hydrol., 324, 210-223, 2006 b.

Haddeland, I., Skaugen, T., and Lettenmaier, D. P.: Hydrologic effects of land and water management in North America and Asia: 1700-1992, Hydrol. Earth Syst. Sci., 11, 1035-1045, doi:10.5194/hess-11-1035-2007, 2007.

Haddeland, I., Clark, D. B., Franssen, W., Ludwig, F., Voß, F., Arnell, N. W., Bertrand, N., Best, M., Folwell, S., Gerten, D., Gomes, S., Gosling, S. N., Hagemann, S., Hanasaki, N., Harding, R., Heinke, J., Kabat, P., Koirala, S., Oki, T., Polcher, J., Stacke, T., Viterbo, P., Weedon, G. P., and Yeh, P.: Multimodel estimate of the global terrestrial water balance: setup and first results, J. Hydrometeorol., 12, 869-884, doi:10.1175/2011JHM1324.1, 2011.

Haddeland, I., Biemans, H., Eisner, S., Flörke, M., Hanasaki, N., Konzmann, M., Ludwig, F., Masaki, Y., Schewe, J., Stacke, T., Tessler, Z. D., Wada, Y., and Wisser, D.: Global water resources affected by human interventions and climate change, P. Natl. Acad. Sci., 111, 3251-3256, doi:10.1073/pnas.1222475110, 2014.

Hanasaki, N., Kanae, S., and Oki, T.: A reservoir operation scheme for global river routing models, J. Hydrol., 327, 22-41, 2006.

Hanasaki, N., Kanae, S., Oki, T., Masuda, K., Motoya, K., Shirakawa, N., Shen, Y., and Tanaka, K.: An integrated model for the assessment of global water resources - Part 1: Model description and input meteorological forcing, Hydrol. Earth Syst. Sci., 12, 1007-1025, doi:10.5194/hess-12-1007-2008, 2008a.

Hanasaki, N., Kanae, S., Oki, T., Masuda, K., Motoya, K., Shirakawa, N., Shen, Y., and Tanaka, K.: An integrated model for the assessment of global water resources - Part 2: Applications and assessments, Hydrol. Earth Syst. Sci., 12, 1027-1037, doi:10.5194/hess-12-1027-2008, 2008b.

Hanasaki, N., Inuzuka, T., Kanae, S., and Oki, T.: An estimation of global virtual water flow and sources of water withdrawal for major crops and livestock products using a global hydrological model, J. Hydrol., 384, 232-244, 2010.

Hanasaki, N., Fujimori, S., Yamamoto, T., Yoshikawa, S., Masaki, Y., Hijioka, Y., Kainuma, M., Kanamori, Y., Masui, T., Takahashi, K., and Kanae, S.: A global water scarcity assessment under Shared Socio-economic Pathways - Part 1: Water use, Hydrol. Earth Syst. Sci., 17, 2375-2391, doi:10.5194/hess-17-23752013, 2013a.

Hanasaki, N., Fujimori, S., Yamamoto, T., Yoshikawa, S., Masaki, Y., Hijioka, Y., Kainuma, M., Kanamori, Y., Masui, T., Takahashi, K., and Kanae, S.: A global water scarcity assessment under Shared Socio-economic Pathways - Part 2: Water availability and scarcity, Hydrol. Earth Syst. Sci., 17, 2393-2413, doi:10.5194/hess-17-2393-2013, 2013b.
Hassanzadeh, E., Nazemi, A., and Elshorbagy, A.: Quantile-Based Downscaling of Precipitation Using Genetic Programming: Application to IDF Curves in Saskatoon, J. Hydrol. Eng., 19, 943955, 2014.

Hejazi, M. I., Edmonds, J., Clarke, L., Kyle, P., Davies, E., Chaturvedi, V., Wise, M., Patel, P., Eom, J., and Calvin, K.: Integrated assessment of global water scarcity over the 21 st century under multiple climate change mitigation policies, Hydrol. Earth Syst. Sci., 18, 2859-2883, doi:10.5194/hess-18-28592014, 2014.

Hill, C., DeLuca, C., Suarez, M., and Da Silva, A.: The architecture of the Earth System Modeling framework, Comput. Sci. Eng., 6, 18-28, 2004.

Hossain, F., Degu, A. M., Yigzaw, W., Burian, S., Niyogi, D., Shepherd, J., and Pielke, R.: Climate feedback-based provisions for dam design, operations, and water management in the 21 st century, J. Hydrol. Eng., 17, 837-850, 2012.

Hossain, M. S. and El-shafie, A.: Intelligent Systems in Optimizing Reservoir Operation Policy: A Review, Water Resour. Manage., 27, 3387-3407, 2013.

Huggins, L. F. and Burney, J. R.: Surface runoff, storage and routing, in: Hydrologic Modeling of Small Watersheds, edited by: Haan, C. T., Johnson, H. P., and Brakensiek, D. L., American Society of Agricultural Engineers, St. Joseph, Michigan, USA, 169-225, 1982.

Hurrell, J., Meehl, G. A., Bader, D., Delworth, T. L., Kirtman, B., and Wielicki, B.: A unified modeling approach to climate system prediction. B. Am. Meteorol. Soc., 90, 1819-1832, 2009.

Hurrell, J. W., Holland, M. M., Gent, P. R., Ghan, S., Kay J. E., Kushner, P. J., Lamarque, J.-F., Large, W. G., Lawrence, D., Lindsay, K., Lipscomb, W. H., Long, M. C., Mahowald, N., Marsh, D. R., Neale, R. B., Rasch, P., Vavrus, S., Vertenstein, M., Bader, D., Collins, W. D., Hack, J. J., Kiehl, J., and Marshall, S.: The community earth system model: a framework for collaborative research, B. Am. Meteorol. Soc., 94, 1339-1360, doi:10.1175/BAMS-D-12-00121.1, 2013.

Ke, Y., Leung, L. R., Huang, M., Coleman, A. M., Li, H., and Wigmosta, M. S.: Development of high resolution land surface parameters for the Community Land Model, Geosci. Model Dev., 5, 1341-1362, doi:10.5194/gmd-5-1341-2012, 2012.

Kollet, S. J. and Maxwell, R. M.: Capturing the influence of groundwater dynamics on land surface processes using an integrated, distributed watershed model, Water Resour. Res., 44, W02402, doi:10.1029/2007WR006004, 2008.

Kollet, S. J., Maxwell, R. M., Woodward, C. S., Smith, S., Vanderborght, J., Vereecken, H., and Simmer, C.: Proof of concept of regional scale hydrologic simulations at hydrologic resolution utilizing massively parallel computer resources, Water Resour. Res., 46, W04201, doi:10.1029/2009WR008730, 2010.

Lai, X., Jiang, J., Yang, G., and Lu, X. X.: Should the Three Gorges Dam be blamed for the extremely low water levels in the middle-lower Yangtze River?, Hydrol. Process., 28, 150-160, doi:10.1002/hyp.10077, 2014.

Lawrence, D. M., Oleson, K. W., Flanner, M. G., Thornton, P. E., Swenson, S. C., Lawrence, P. J., Zeng, X., Yang, Z.-L., Levis, S., Sakaguchi, K., Bonan, G. B., and Slater, A. G.: Parameterization improvements and functional and structural advances in Version 4 of the Community Land Model, J. Adv. Model. Earth Syst., 3, M03001, doi:10.1029/2011MS00045, 2011. 
Lawrence, D. M., Maxwell, R., Swenson, S., Lopez, S., and Famiglietti, J.: Challenges of Representing and Predicting MultiScale Human-Water Cycle Interactions in Terrestrial Systems, available at: http://climatemodeling.science.energy.gov/ sites/default/files/Topic_330final.pdf (last access: 6 May 2014), 2012.

Lecca, G., Petitdidier, M., Hluchy, L., Ivanovic, M., Kussul, N., Ray, N., and Thieron V.: Grid computing technology for hydrological applications, J. Hydrol., 403, 186-199, 2011.

Lehner, B. and Döll, P.: Development and validation of a global database of lakes, reservoirs and wetlands, J. Hydrol., 296, 1-22, 2004.

Lehner, B. and Grill, G.: Global river hydrography and network routing: baseline data and new approaches to study the world's large river systems, Hydrol. Process., 27, 2171-2186, doi:10.1002/hyp.9740, 2013.

Lehner, B., Verdin, K., and Jarvis, A.: New Global Hydrography Derived From Spaceborne Elevation Data, Eos Trans. AGU, 89, 93-94, doi:10.1029/2008EO100001, 2008.

Lehner, B., Liermann, C. R., Revenga, C., Vörösmarty, C., Fekete, B., Crouzet, P., Döll, P., Endejan, M., Frenken, K., Magome, J., Nilsson, C., Robertson, J. C., Rödel, R., Sindorf, N., and Wisser, D.: High-resolution mapping of the world's reservoirs and dams for sustainable river-flow management, Front. Ecol. Environ., 9, 494-502, 2011.

Lettenmaier, D. P. and Milly, P. C. D.: Land waters and sea level, Nat. Geosci., 2, 452-454, 2009.

Levis, S. and Sacks, W.: Technical descriptions of the interactive crop management (CLM4CNcrop) and interactive irrigation models in version 4 of the Community Land Model, http://www.cesm.ucar.edu/models/cesm1.1/ clm/CLMcropANDirrigTechDescriptions.pdf (last access: 6 May 2014), 2011.

Levis, S., Bonan, G. B., Kluzek, E., Thornton, P. E., Jones, A., Sacks, W. J., and Kucharik, C. J.: Interactive Crop Management in the Community Earth System Model (CESM1): Seasonal Influences on Land-Atmosphere Fluxes, J. Climate, 25, 48394859, 2012.

Li, H., Huang, M., Wigmosta, M., Ke, Y., Coleman, A., Leung, L. R., Wang, A., and Ricciuto, D. M.: Evaluating runoff simulations from the Community Land Model 4.0 using observations from flux towers and a mountainous watershed, J. Geophys. Res., 116, D24120, doi:10.1029/2011JD016276, 2011.

Li, H., Wigmosta, M. S., Wu, H., Huang, M., Ke, Y., Coleman, A. M., and Leung, L. R.: A physically based runoff routing model for land surface and earth system models, J. Hydrometeorol., 14, 808-828, 2013.

Liang, X., Lettenmaier, D. P., Wood, E. F., and Burges, S. J.: A simple hydrologically based model of land surface water and energy fluxes for general circulation models, J. Geophys. Res.-Atmos., 99, 14415-14428, 1994.

Liebe, J., Van De Giesen, N., and Andreini, M.: Estimation of small reservoir storage capacities in a semi-arid environment: A case study in the Upper East Region of Ghana, Phys. Chem. Earth A/B/C, 30, 448-454, 2005.

Liu, C. and Zheng, H.: South-to-north water transfer schemes for China, Int. J. Water Resour. Develop., 18, 453-471, 2002.

Liu, J. and Yang, W.: Water sustainability for China and beyond, Science, 337, 649-650, 2012.
Liu, J., Zang, C., Tian, S., Liu, J., Yang, H., Jia, S., You, L., Liu, B., and Zhang, M.: Water conservancy projects in China: achievements, challenges and way forward, Global Environ. Change, 23, 633-643, 2013.

Liu, S., Wei, Y., Post, W. M., Cook, R. B., Schaefer, K., and Thornton, M. M.: The Unified North American Soil Map and its implication on the soil organic carbon stock in North America, Biogeosciences, 10, 2915-2930, doi:10.5194/bg-10-2915-2013, 2013.

Lohmann, D., Nolte-Holube, R., and Raschke, E.: A large-scale horizontal routing model to be coupled to land surface parametrization schemes, Tellus A, 48, 708-721, doi:10.1034/j.16000870.1996.t01-3-00009.x, 1996.

Lohmann, D., Raschke, E., Nijssen, B., and Lettenmaier, D. P.: Regional scale hydrology: I. Formulation of the VIC-2L model coupled to a routing model, Hydrolog. Sci. J., 43, 131-141, 1998.

MacKay, M. D.: A process oriented small lake dynamical scheme for coupled climate modeling applications, in: Vol. 1, AGU Fall Meeting Abstracts, San Francisco, p. 1359, 2011.

MacKay, M. D. and Seglenieks, F.: On the simulation of Laurentian Great Lakes water levels under projections of global climate change, Climatic Change, 117, 55-67, 2013.

MacKay, M. D., Neale, P. J., Arp, C. D., De Senerpont Domis, L. N., Fang, X., Gal, G., Jöhnk, K. D., Kirillin, G., Lenters, J. D., Litchman, E., MacIntyre, S., Marsh, P., Melack, J., Mooij, W. M., Peeters, F., Quesada, A., Schladow, S. G., Schmid, M., Spence, C., and Stokes, S. L.: Modeling lakes and reservoirs in the climate system, Limnol. Oceanogr., 54, 2315-2329, 2009.

Maxwell, R. M. and Miller, N. L.: Development of a coupled land surface and groundwater model, J. Hydrometeorol, 6, 233-247, 2005.

Maxwell, R. M., Chow, F. K., and Kollet, S. J.: The groundwaterland-surface-atmosphere connection: soil moisture effects on the atmospheric boundary layer in fully-coupled simulations, Adv. Water Resour., 30, 2447-2466, 2007.

Maxwell, R. M., Lundquist, J. K., Mirocha, J. D., Smith, S. G., Woodward, C. S., and Tompson, A. F. B.: Development of a coupled groundwater-atmosphere model, Mon. Weather Rev., 139, 96-116, 2011.

Meigh, J. R., McKenzie, A. A., and Sene, K. J.: A grid-based approach to water scarcity estimates for eastern and southern Africa, Water Resour. Manage., 13, 85-115, 1999.

Meybeck, M.: Global analysis of river systems: from Earth system controls to Anthropocene syndromes, Philos. T. Roy. Soc. Lond. B, 358, 1935-1955, 2003.

Michetti, M. and Zampieri, M.: Climate-Human-Land Interactions: A Review of Major Modelling Approaches. Land, 3, 793-833, doi:10.3390/land3030793, 2014.

Mu, Q., Zhao, M., and Running, S. W.: Development of a global evapotranspiration algorithm based on MODIS and global meteorology data, Remote Sens. Environ., 111, 519-536, 2007.

Mu, Q., Zhao, M., and Running, S. W.: Improvements to a MODIS global terrestrial evapotranspiration algorithm, Remote Sens. Environ., 115, 1781-1800, 2011.

Müller Schmied, H., Eisner, S., Franz, D., Wattenbach, M., Portmann, F. T., Flörke, M., and Döll, P.: Sensitivity of simulated global-scale freshwater fluxes and storages to input data, hydrological model structure, human water use and calibration, Hy- 
drol. Earth Syst. Sci., 18, 3511-3538, doi:10.5194/hess-18-35112014, 2014.

Nakayama, T. and Shankman, D.: Impact of the Three-Gorges Dam and water transfer project on Changjiang floods, Global Planet. Change, 100, 38-50, 2013a.

Nakayama, T. and Shankman, D.: Evaluation of uneven water resource and relation between anthropogenic water withdrawal and ecosystem degradation in Changjiang and Yellow River basins, Hydrol. Process., 27, 3350-3362, doi:10.1002/hyp.9835, 2013 b.

Nazemi, A. and Wheater, H. S.: Assessing the Vulnerability of Water Supply to Changing Streamflow Conditions, Eos Trans. AGU, 95, 288, doi:10.1002/2014EO320007, 2014a.

Nazemi, A. and Wheater, H. S.: How can the uncertainty in the natural inflow regime propagate into the assessment of water resource systems?, Adv. Water Resour., 63, 131-142, doi:10.1016/j.advwatres.2013.11.009, 2014b.

Nazemi, A. and Wheater, H. S.: On inclusion of water resource management in Earth System models - Part 1: Problem definition and representation of water demand, Hydrol. Earth Syst. Sci., 19, 33-61, doi:10.5194/hess-19-33-2015, 2015.

Nazemi, A., Akbarzadeh, M. R., and Hosseini, S. M.: Fuzzystochastic linear programming in water resources engineering, in: Proceeding of Fuzzy Information Processing Society, NAFIPS 2002, IEEE, New Jersey, USA, 227-232, doi:10.1109/NAFIPS.2002.1018060, 2002.

Nazemi, A., Hosseini, S. M., and Akbarzadeh-T, M. R.: Soft computing-based nonlinear fusion algorithms for describing nonDarcy flow in porous media, J. Hydraul. Res., 44, 269-282, 2006a.

Nazemi, A., Yao, X., and Chan, A. H.: Extracting a set of robust Pareto-optimal parameters for hydrologic models using NSGAII and SCEM, in: Proceedings of IEEE Congress on Evolutionary Computation (CEC 2006), Vancouver, Canada, 1901-1908, doi:10.1109/CEC.2006.1688539, 2006b.

Nazemi, A., Chan, A. H., and Yao, X.: Selecting representative parameters of rainfall-runoff models using multi-objective calibration results and a fuzzy clustering algorithm, in: BHS 10th National Hydrology Symposium, Exeter, UK, 13-20, 2008.

Nazemi, A., Wheater, H. S., Chun, K. P., and Elshorbagy, A.: A stochastic reconstruction framework for analysis of water resource system vulnerability to climate-induced changes in river flow regime, Water Resour. Res., 49, 291-305, doi:10.1029/2012WR012755, 2013.

Nilsson, C., Reidy, C. A., Dynesius, M., and Revenga, C.: Fragmentation and flow regulation of the world's large river systems, Science, 308, 405-408, 2005.

Oki, T. and Kanae, S.: Global hydrological cycles and world water resources, Science, 313, 1068-1072, 2006.

Oki, T. and Sud, Y. C.: Design of Total Runoff Integrating Pathways (TRIP) - A global river channel network, Earth Interact., 2, 1-37, 1998.

Oki, T., Agata, Y., Kanae, S., Saruhashi, T., Yang, D., and Musiake, K.: Global assessment of current water resources using total runoff integrating pathways, Hydrolog. Sci. J., 46, 983-995, 2001.

Oki, T., Blyth, E. M., Berbery, E. H., and Alcaraz-Segura, D.: Land Use and Land Cover Changes and Their Impacts on Hydroclimate, Ecosystems and Society, in: Climate Science for Serv- ing Society, edited by: Asrar, G. R. and Hurrell, J. W., Springer Netherlands, 185-203, 2013.

Oleson, K. W., Dai, Y., Bonan, G. B., Bosilovichm, M., Dickinson, R., Dirmeyer, P., Hoffman, F., Houser, P., Levis, S., Niu, G.-Y., Thornton, P., Vertenstein, M., Yang, Z., and Zeng, X.: Technical description of the community land model (CLM), NCAR Tech. Note NCAR/TN-461+STR, 173 pp., doi:10.5065/D6N877R0, http://www.cesm.ucar.edu/models/ cesm1.0/clm/CLM4_Tech_Note.pdf (last access: 28 December 2014), 2004.

Oleson, K. W., Niu, G. Y., Yang, Z. L., Lawrence, D. M., Thornton, P. E., Lawrence, P. J., Stöckli, R., Dickinson, R. E., Bonan, G. B., Levis, S., Dai, A., and Qian, T.: Improvements to the Community Land Model and their impact on the hydrological cycle, J. Geophys. Res.-Biogeo., 113, G01021, doi:10.1029/2007JG000563, 2008.

Pietroniro, A., Fortin, V., Kouwen, N., Neal, C., Turcotte, R., Davison, B., Verseghy, D., Soulis, E. D., Caldwell, R., Evora, N., and Pellerin, P.: Development of the MESH modelling system for hydrological ensemble forecasting of the Laurentian Great Lakes at the regional scale, Hydrol. Earth Syst. Sci., 11, 1279-1294, doi:10.5194/hess-11-1279-2007, 2007.

Pokhrel, Y. N., Hanasaki, N., Koirala, S., Cho, J., Yeh, P. J.-F., Kim, H., Kanae, S., and Oki, T.: Incorporating anthropogenic water regulation modules into a land surface model, J. Hydrometeorol., 13, 255-269, 2012a.

Pokhrel, Y. N., Hanasaki, N., Yeh, P. J., Yamada, T. J., Kanae, S., and Oki, T.: Model estimates of sea-level change due to anthropogenic impacts on terrestrial water storage, Nat. Geosci., 5, 389-392, doi:10.1038/ngeo1476, 2012b.

Polcher, J.: Interactive comment on "On inclusion of water resource management in Earth System models - Part 1: Problem definition and representation of water demand" by A. Nazemi and H. S. Wheater, Hydrol. Earth Syst. Sci. Discuss., 11, C3403C3410, 2014.

Polcher, J., Bertrand, N., Biemans, H., Clark, D. B., Floerke, M., Gedney, N., Gerten, D., Stacke, T., van Vliet, M., and Voss, F.: Improvements in hydrological processes in general hydrological models and land surface models within WATCH, WATCH Technical Report Number 34, available at: http://www.eu-watch.org/ publications/technical-reports (last access: 6 May 2014), 2011.

Ponce, V. M. and Changanti, P. V.: Variable-parameter MuskingumCunge method revisited, J. Hydrol., 162, 433-439, 1994.

Popper, K.: The logic of scientific discovery, 1995 Edn., Routledge, London, 1959.

Postel, S. L., Daily, G. C., and Ehrlich, P. R.: Human appropriation of renewable fresh water, Science, 271, 785-788, 1996.

Prudhomme, C., Giuntoli, I., Robinson, E. L., Clark, D. B., Arnell, N. W., Dankers, R., Fekete, B. M., Franssen, W., Gerten, D., Gosling, S. N., Hagemann, S., Hannah, D. M., Kim, H., Masaki, Y., Satoh, Y., Stacke, T., Wada, Y., and Wisser, D.: Hydrological droughts in the 21 st century, hotspots and uncertainties from a global multimodel ensemble experiment, P. Natl. Acad. Sci USA, 111, 3262-3267, doi:10.1073/pnas.1222473110, 2014.

Pryke, A., Mostaghim, S., and Nazemi, A.: Heatmap visualization of population based multi objective algorithms, In Evolutionary multi-criterion optimization, Springer, Berlin, Heidelberg, 361375, 2007. 
Rani, D. and Moreira, M. M.: Simulation-optimization modeling: a survey and potential application in reservoir systems operation, Water Resour. Manage., 24, 1107-1138, 2010.

Revelle, C., Joeres, E., and Kirby, W.: The Linear Decision Rule in Reservoir Management and Design: 1. Development of the Stochastic Model, Water Resour. Res., 5, 767-777, doi:10.1029/WR005i004p00767, 1969.

Rodell, M., Chen, J., Kato, H., Famiglietti, J. S., Nigro, J., and Wilson, C. R.: Estimating groundwater storage changes in the Mississippi River basin (USA) using GRACE, Hydrogeol. J., 15, 159-166, 2007.

Rodell, M., Velicogna, I., and Famiglietti, J. S.: Satellite-based estimates of groundwater depletion in India, Nature, 460, 999-1002, 2009.

Rosenzweig, C., Elliott, J., Deryng, D., Ruane, A. C., Müller, C., Arneth, A., Boote, K. J., Folberth, C., Glotter, M., Khabarov, N., Neumann, K., Piontek, F., Pugh, T. A. M., Schmid, E., Stehfest, E., Yang, H., and Jones, J. W.: Assessing agricultural risks of climate change in the 21 st century in a global gridded crop model intercomparison, P. Natl. Acad. Sci. USA, 111, 32683273, doi:10.1073/pnas.1222463110, 2014.

Rosolem, R., Gupta, H. V., Shuttleworth, W. J., Zeng, X., and de Gonçalves, L. G. G.: A fully multiple-criteria implementation of the Sobol' method for parameter sensitivity analysis, J. Geophys. Res., 117, D07103, doi:10.1029/2011JD016355, 2012.

Rosolem, R., Gupta, H. V., Shuttleworth, W. J., de Gonçalves, L. G. G., and Zeng, X.: Towards a comprehensive approach to parameter estimation in land surface parameterization schemes, Hydrol. Process., 27, 2075-2097, doi:10.1002/hyp.9362, 2013.

Rost, S., Gerten, D., Bondeau, A., Luncht, W., Rohwer, J., and Schaphoff, S.: Agricultural green and blue water consumption and its influence on the global water system, Water Resour. Res., 44, W09405, doi:10.1029/2007WR006331, 2008.

Rouholahnejad, E., Abbaspour, K. C., Vejdani, M., Srinivasan, R., Schulin, R., and Lehmann, A.: A parallelization framework for calibration of hydrological models, Environ. Model. Softw., 31, 28-36, 2012.

Sato, H., Ito, A., Ito, A., Ise, T., and Kato, E.: Current status and future of land surface models, Soil Sci. and Plant Nutr., doi:10.1080/00380768.2014.917593, in press, 2014.

Savtchenko, A., Ouzounov, D., Ahmad, S., Acker, J., Leptoukh, G., Koziana, J., and Nickless, D.: Terra and Aqua MODIS products available from NASA GES DAAC, Adv. Space Res., 34, 710714, 2004.

Schewe, J., Heinke, J., Gerten, D., Haddeland, I., Arnell, N. W., Clark, D. B., Dankers, R., Eisner, S., Fekete, B. M., ColónGonzález, F. J., Gosling, S. N., Kim, H., Liu, X., Masaki, Y., Portmann, F. T., Satoh, Y., Stacke, T., Tang, Q., Wada, Y., Wisser, D., Albrecht, T., Frieler, K., Piontek, F., Warszawski, L., and Kabat, P.: Multimodel assessment of water scarcity under climate change, P. Natl. Acad. Sci. USA, 111, 3245-3250, doi:10.1073/pnas.1222460110, 2014.

Schiermeier, Q.: Water risk as world warms, Nature, 505, 7481, doi:10.1038/505010a, 2014.

Schwiegelshohn, U., Badia, R. M., Bubak, M., Danelutto, M., Dustdar, S., Gagliardi, F., Geiger, A., Hluchy, L., Kranzlmüller, D., Erwin Laure, E., Priol, T., Reinefeld, A., Resch, M., Reuter, A., Rienhoff, O., Rüter, T., Sloot, S., Talia, D., Ullmann, K.,
Yahyapour, R., and von Voigt, G.: Perspectives on grid computing, Future Gener. Comp. Sy., 26, 1104-1115, 2010.

Siebert, S., Burke, J., Faures, J. M., Frenken, K., Hoogeveen, J., Döll, P., and Portmann, F. T.: Groundwater use for irrigation - a global inventory, Hydrol. Earth Syst. Sci., 14, 1863-1880, doi:10.5194/hess-14-1863-2010, 2010.

Skliris, N. and Lascaratos, A.: Impacts of the Nile River damming on the thermohaline circulation and water mass characteristics of the Mediterranean Sea, J. Mar. Syst., 52, 121-143, doi:10.1016/j.jmarsys.2004.02.005, 2004.

Smith, M. J., Palmer, P. I., Purves, D. W., Vanderwel, M. C., Lyutsarev, V., Calderhead, B., Joppa, L. N., Bishop, C. M., and Emmott, S.: Changing How Earth System Modeling is Done to Provide More Useful Information for Decision Making, Science, and Society, B. Am. Meteorol. Soc., 95, 1453-1464, doi:10.1175/BAMS-D-13-00080.1, 2014.

Sorooshian, S., Li, J., Hsu, K.-L., and Gao, X.: How significant is the impact of irrigation on the local hydroclimate in California's Central Valley? Comparison of model results with ground and remote-sensing data, J. Geophys. Res., 116, D06102, doi:10.1029/2010JD014775, 2011a.

Sorooshian, S., AghaKouchak, A., Arkin, P., Eylander, J., FoufoulaGeorgiou, E., Harmon, R., Hendrickx, J. M. H., Imam, B., Kuligowski, R., Skahill, B., and Skofronick-Jackson, G.: Advanced concepts on remote sensing of precipitation at multiple scales, B. Am. Meteorol. Soc., 92, 1353-1357, 2011 b.

Strzepek, K., Schlosser, A., Farmer, W., Awadalla, S., Baker, J., Rosegrant, M., and Gao, X.: Modeling the global water resource system in an integrated assessment modeling framework: IGSM-WRS, MIT Joint Program on the Science and Policy of Global Change, Report No. 189, available at: http://dspace.mit. edu/handle/1721.1/61767 (last access: 6 May 2014), 2010.

Strzepek, K., Schlosser, A., Gueneau, A., Gao, X., Blanc, É., Fant, C., Rasheed, B., and Jacoby, H. D.: Modeling water resource system under climate change: IGSM-WRS, MIT Joint Program on the Science and Policy of Global Change, Report No. 236, http: //dspace.mit.edu/handle/1721.1/75774 (last access: 6 May 2014), 2012.

Sun, A. Y., Green, R., Swenson, S., and Rodell, M.: Toward calibration of regional groundwater models using GRACE data, J. Hydrol., 422, 1-9, 2012.

Swenson, S. C., Lawrence, D. M., and Lee, H.: Improved simulation of the terrestrial hydrological cycle in permafrost regions by the Community Land Model, J. Adv. Model. Earth Syst., 4, M08002, doi:10.1029/2012MS000165, 2012.

Syvitski, J. P. M., Vorosmarty, C. J., Kettner, A. J., and Green, P.: Impact of humans on the flux of terrestrial sediment to the global coastal ocean, Science, 308, 376-380, 2005.

Takata, K., Emori, S., and Watanabe, T.: Development of the minimal advanced treatments of surface interaction and runoff, Global Planet. Change, 38, 209-222, 2003.

Takeuchi, K.: Least marginal environmental impact rule for reservoir development, Hydrolog. Sci. J., 42, 583-597, 1997.

Tang, Q., Gao, H., Yeh, P., Oki, T., Su, F., and Lettenmaier, D. P.: Dynamics of Terrestrial Water Storage Change from Satellite and Surface Observations and Modeling, J. Hydrometeorol., 11, 156170, 2010. 
Tapley, B. D., Bettadpur, S., Ries, J. C., Thompson, P. F., and Watkins, M. M.: GRACE measurements of mass variability in the Earth system, Science, 305, 503-505, 2004.

Taylor, R. G., Scanlon, B., Döll, P., Rodell, M., van Beek, R., Wada, Y., Longuevergne, L., Leblanc, M., Famiglietti, J. S., Edmunds, M., Konikow, L., Green, T. R., Chen, J., Taniguchi, M., Bierkens, M. F. P., MacDonald, A., Fan, Y., Maxwell, R. M., Yechieli, Y., Gurdak, J. J., Allen, D. M., Shamsudduha, M., Hiscock, K., Yeh, P. J.-F., Holman, I., and Treidel, H.: Ground water and climate change, Nat. Clim. Change, 3, 322-329, 2013.

Tebakari, T., Yoshitani, J., and Suvanpimol, P.: Impact of large-scale reservoir operation on flow regime in the Chao Phraya River basin, Thailand, Hydrol. Process., 26, 2411-2420, 2012.

Tesfa, T. K., Li, H.-Y., Leung, L. R., Huang, M., Ke, Y., Sun, Y., and Liu, Y.: A subbasin-based framework to represent land surface processes in an Earth system model, Geosci. Model Dev., 7, 947963, doi:10.5194/gmd-7-947-2014, 2014.

Trenberth, K. E. and Asrar, G. R.: Challenges and opportunities in water cycle research: WCRP contributions, Surv. Geophys., 35, 515-532, 2012.

USGS: Water Use in the United States, http://water.usgs.gov/ watuse/data/2005/index.html (last access: 6 May 2014), 2011.

van Beek, L. P. H. and Bierkens, M. F. P.: The Global Hydrological Model PCR-GLOBWB: Conceptualization, Parameterization and Verification, Report Department of Physical Geography, Utrecht University, Utrecht, the Netherlands, http: //vanbeek.geo.uu.nl/suppinfo/vanbeekbierkens2009.pdf (last access: 6 May 2014), 2009.

van Beek, L. P. H., Wada, Y., and Bierkens, M. F. P.: Global monthly water stress: 1. Water balance and water availability, Water Resour. Res., 47, W07517, doi:10.1029/2010WR009791, 2011.

van Dijk, A. I. J. M. and Renzullo, L. J.: Water resource monitoring systems and the role of satellite observations, Hydrol. Earth Syst. Sci., 15, 39-55, doi:10.5194/hess-15-39-2011, 2011.

Voisin, N., Li, H., Ward, D., Huang, M., Wigmosta, M., and Leung, L. R.: On an improved sub-regional water resources management representation for integration into earth system models, Hydrol. Earth Syst. Sci., 17, 3605-3622, doi:10.5194/hess-173605-2013, 2013a.

Voisin, N., Liu, L., Hejazi, M., Tesfa, T., Li, H., Huang, M., Liu, Y., and Leung, L. R.: One-way coupling of an integrated assessment model and a water resources model: evaluation and implications of future changes over the US Midwest, Hydrol. Earth Syst. Sci., 17, 4555-4575, doi:10.5194/hess-17-4555-2013, 2013b.

Von Bloh, W., Rost, S., Gerten, D., and Lucht, W.: Efficient parallelization of a dynamic global vegetation model with river routing, Environ. Model. Softw., 25, 685-690, 2010.

Vörösmarty, C. J., Sharma, K. P., Fekete, B. M., Copeland, A. H., Holden, J., Marble, J., and Lough, J. A.: The storage and aging of continental runoff in large reservoir systems of the world, Ambio, 26, 210-219, 1997.

Vörösmarty, C. J., Federer, C. A., and Schloss A. L.: Potential evaporation functions compared on US watersheds: Possible implications for global-scale water balance and terrestrial ecosystem modeling, J. Hydrol., 207, 147-169, 1998.

Vörösmarty, C. J., Meybeck, M., Fekete, B., Sharma, K., Green, P., and Syvitski, J. P.: Anthropogenic sediment retention: major global impact from registered river impoundments, Global Planet. Change, 39, 169-190, 2003.
Vörösmarty, C. J., McIntyre, P. B., Gessner, M. O., Dudgeon, D., Prusevich, A., Green, P., Glidden, S., Bunn, S. E., Sullivan, C. A., Reidy Liermann, C., and Davies, P. M.: Global threats to human water security and river biodiversity, Nature, 467, 555-561, 2010.

Wada, Y., van Beek, L. P. H., van Kempen, C. M., Reckman, J. W. T. M., Vasak, S., and Bierkens, M. F. P.: Global depletion of groundwater resources, Geophys. Res. Lett., 37, L20402, doi:10.1029/2010GL044571, 2010.

Wada, Y., van Beek, L. P. H., Viviroli, D., Dürr, H. H., Weingartner, R., and Bierkens, M. F. P.: Global monthly water stress: 2. Water demand and severity of water stress, Water Resour. Res., 47, W07518, doi:10.1029/2010WR009792, 2011.

Wada, Y., van Beek, L. P. H., and Bierkens, M. F. P.: Nonsustainable groundwater sustaining irrigation: A global assessment, Water Resour. Res., 48, W00L06, doi:10.1029/2011WR010562, 2012.

Wada, Y., Wisser, D., Eisner, S., Flörke, M., Gerten, D., Haddeland, I., Hanasaki, N., Masaki, Y., Portmann, F. T., Stacke, T., Tessler, Z., and Schewe, J.: Multimodel projections and uncertainties of irrigation water demand under climate change, Geophys. Res. Lett., 40, 4626-4632, 2013.

Wada, Y., Wisser, D., and Bierkens, M. F. P.: Global modeling of withdrawal, allocation and consumptive use of surface water and groundwater resources, Earth Syst. Dynam., 5, 15-40, doi:10.5194/esd-5-15-2014, 2014.

Wade Miller, G.: Integrated concepts in water reuse: managing global water needs, Desalination, 187, 65-75, 2006.

Wagener, T., Wheater, H. S., and Gupta, H. V.: Rainfall-Runoff Modelling in Gauged and Ungauged Catchments, Imperial College Press, London, UK, 2004.

Wang, Y., Leung, L. R., McGregor, J. L., Lee, D. K., Wang, W. C., Ding, Y., and Kimura, F.: Regional climate modeling: progress, challenges, and prospects, J. Meteorol. Soc. Jpn., 82, 1599-1628, 2004.

Wehner, M., Oliker, L., and Shalf, J.: Towards ultra-high resolution models of climate and weather, Int. J. High Perform. Comput. Appl., 22, 149-165, 2008.

Wheater, H. and Gober, P.: Water security in the Canadian Prairies: science and management challenges, Philos. T. Roy. Soc. A, 371, 20120409, doi:10.1098/rsta.2012.0409, 2013.

Williams, D. L., Goward, S., and Arvidson, T.: Landsat: Yesterday, today, and tomorrow, Photogramm. Eng. Remote Sens., 72, 1171-1178, 2006.

Wisser, D., Fekete, B. M., Vörösmarty, C. J., and Schumann, A. H.: Reconstructing 20th century global hydrography: a contribution to the Global Terrestrial Network-Hydrology (GTN-H), Hydrol. Earth Syst. Sci., 14, 1-24, doi:10.5194/hess-14-1-2010, 2010.

Wood, E. F., Roundy, J. K., Troy, T. J., van Beek, L. P. H., Bierkens, M. F. P., Blyth, E., de Roo, A., Döll, P., Ek, M., Famiglietti, J., Gochis, D., van de Giesen, N., Houser, P., Jaffé, P. R., Kollet, S., Lehner, B., Lettenmaier, D. P., Peters-Lidard, C., Sivapalan, M., Sheffield, J., Wade, A., and Whitehead, P.: Hyperresolution global land surface modeling: meeting a grand challenge for monitoring Earth's terrestrial water, Water Resour. Res., 47, W05301, doi:10.1029/2010WR010090, 2011.

Wu, Y. and Chen, J.: An Operation-Based Scheme for a Multiyear and Multipurpose Reservoir to Enhance Macroscale Hydrologic Models, J. Hydrometeorol., 13, 270-283, 2012. 
Wu, Y., Chen, J., and Sivakumar, B.: Numerical Modeling of Operation and Hydrologic Effects of Xinfengjiang Reservoir in Southern China, in: Proc. MODSIM 2007 International Congress on Modelling and Simulation, http://mssanz.org.au/ MODSIM07/papers/24_s17/NumericalModelings17_Wu.pdf, last access: 6 May 2014, 1561-1567, 2007.

Wu, Y., Li, T., Sun, L., and Chen, J.: Parallelization of a hydrological model using the message passing interface, Environ. Model. Softw., 43, 124-132, 2013.

Ye, A., Duan, Q., Chu, W., Xu, J., and Mao, Y.: The impact of the South-North Water Transfer Project (CTP)'s central route on groundwater table in the Hai River basin, North China, Hydrol. Process., 28, 5755-5768, doi::10.1002/hyp.10081, 2013.

Yilmaz, M. T., Anderson, M. C., Zaitchik, B., Hain, C. R., Crow, W. T., Ozdogan, M., Chun, J. A., and Evans, J.: Comparison of prognostic and diagnostic surface flux modeling approaches over the Nile River basin, Water Resour. Res., 50, 386-408, doi:10.1002/2013WR014194, 2014.
Yoshikawa, S., Cho, J., Yamada, H. G., Hanasaki, N., and Kanae, S.: An assessment of global net irrigation water requirements from various water supply sources to sustain irrigation: rivers and reservoirs (1960-2050), Hydrol. Earth Syst. Sci., 18, 4289-4310, doi:10.5194/hess-18-4289-2014, 2014.

Zektser, I. S. and Lorne, E.: Groundwater resources of the world: and their use, http://unesdoc.unesco.org/images/0013/001344/ 134433e.pdf (last access: 6 May 2014), 2004.

Zhao, F. and Shepherd, M.: Precipitation Changes near Three Gorges Dam, China, Part I: A Spatiotemporal Validation Analysis, J. Hydrometeorol., 13, 735-745, 2012. 